\title{
Karşılaştırmalı Çerçevede Avrupa Parlamentosunda Siyasal Gruplar*
}

\author{
Arda Görkem YATAĞAN ${ }^{1}$ Elvettin AKMAN ${ }^{2} \quad$ Hakan Mehmet KİRIŞ̧$^{3}$ \\ ***Bilim Uzmanı, Süleyman Demirel Üniversitesi, Sosyal Bilimler Enstitüsü, Uluslararası İlişkiler Anabilim Dalı AB Çalışmaları Bilim Dalı \\ Yüksek Lisans Programı \\ ***Yrd. Doç. Dr, Süleyman Demirel Üniversitesi, İIBF, Siyaset Bilimi ve Kamu Yönetimi Bölümü Öğretim Üyesi \\ ${ }^{* * * * * *}$ Doç. Dr, Süleyman Demirel Üniversitesi, İ̈BF, Siyaset Bilimi ve Kamu Yönetimi Bölümü Öğretim Üyesi
}

\begin{abstract}
Özet
AB üye ülkelerinde yaşayan yaklaşı 510 milyon nüfusu temsil eden ve 390 milyon seçmenin oy kullanma hakkına sahip olduğu Avrupa Parlamentosu, $\mathrm{AB}$ bünyesinde doğrudan vatandaşların oyu ile seçilen tek kurumdur. Bir siyasi güç olarak temel işlevi $\mathrm{AB}$ politikalarının hazırlanması için gereken kararları üretmek olan Avrupa Parlamentosu çatısı altında birbirlerine yakın ya da benzer siyasi tutumları olan, bazen de farklılıkları olmasına rağmen ortak payda da bir araya gelen ulusal partiler siyasi grupları oluşturmaktadırlar. 2014 yılında gerçekleştirilen seçimler neticesinde sekiz siyasi parti grubu bulunan Avrupa Parlamentosu, üye ülkelerde yaşayan seçmenlere seçimler esnasında farklı politikalar sunan ve birlik içerisinde politika yapımını üstlenen önemli bir kurumdur. Bu açıdan çalışmada siyasi grupların işlev, konum ve politikalarının neler olduğu ortaya konulduktan sonra ortaya çıkan farklılıklar ele alınmıştır
\end{abstract}

Anahtar Kelimeler: Avrupa Parlamentosu, Siyasal Gruplar, Avrupa Seçimleri, Grup Politikaları.

\section{Political Groups in European Parliament Within the Comparative Perspective}

\begin{abstract}
Representing approximately 510 million population living in European Union (EU) member states, European Parliament, where 390 million voters have right to vote, is the only institution to be elected directly by the votes of citizens within EU. Under the roof of European Parliament, with its main function of producing the decisions required for the production of EU policies as a political power, national parties sharing close or similar political attitudes, and sometimes gathering under common grounds, constitutes political groups. Sheltering eight political party group according to the 2014 elections, European Parliament is a significant institution offering various policies to the voters of member countries during the elections and undertaking the responsibility of policymaking within the union. Within this context, in this study, the functions, places and policies of political groups are explained and the differences among them are stated.
\end{abstract}

Key Words: European Parliament, Political Groups, European Elections, Group Policies.

\section{Giriş}

Birleşmiş bir Avrupa düşüncesini anlamak zor olabilir. Bununla birlikte ulus devletler çağı öncesinde Avrupa'yı birleşmiş bir duruma getiren pek çok dönemden söz etmek mümkündür. Birleşmiş Avrupa'nın ilk örneği belki Roma İmparatorluğu'dur. En geniş siyasi sınırlarıyla Roma, bilinen dünyaya ve bu eski kıtaya hükmeden ve pax romana adıyla anılan bir güç ve istikrar alanı oluşturmuştur. 2000 yılında gösterime giren ünlü Hollywood yapımı Gladiator filmi, gücünün zirvesindeki Roma İmparatorluğu, Afrika çöllerinden Kuzey İngiltere'ye kadar geniş bir alana yayılmıştı, Dünya nüfusunun çeyreğinden fazlası sezarların yönetimi altında yaşıyordu epigrafiyla başlar. Sonrasında filmin ana figürü olan Maximuseurocentric bir tarz ile dünyanın pek çok yerini gördüğünden Roma dışında kalan yerlerin karanlık olduğundan söz eder. ${ }^{1}$ Roma'nın ardından

* Bu makalenin temeli, Arda Görkem Yatağan'ın, Doç. Dr. Hakan Mehmet Kiriş danışmanlığında başlayıp Yrd. Doç. Dr. Elvettin Akman danışmanlığında Süleyman Demirel Üniversitesi Sosyal Bilimler Enstitüsü Uluslararası İlişkiler ABD AB Çalışmaları bilim alanında tamamladığı, "Avrupa Parlamentosu'nda Siyasi Gruplar: Oluşum, İşleyiş ve Partilerin Geleceği Tartışmasındaki Yerleri” dinsel boyut tek Avrupa düşüncesi üzerinde durmuştur. Dinin yanında hanedanlar ve onların savaş, veraset vb. yollarla edindikleri topraklar, eski Avrupa'yı şekillendiren önemli bir dinamik olmuştur (Roberts, 2010). Napolyon ve Hitler'in tüm Avrupa'yı işgal planları da bu çerçeveye eklenebilir. Söz konusu bu dönemler, Avrupalılık fikrinin oluşmasında etkili olmuş görünmektedir. Şüphesiz ulus devletler, bu açıdan Avrupa'nın birliğini ortadan kaldırmış ve kıtanın değişik coğrafyalarında asgari de olsa tarihsel bir benzeşmeyi oluşturan topluluklar, belli siyasi iradelerin egemenliği altında, giderek diğerlerinden farklılaşan ve bu farklılaşmayı bilinçli ulusal kimliklerin parçası haline getiren bir dönüşüm geçirmişlerdir. Yine de Avrupalılık fikrinin ortadan kalktığını iddia etmek oldukça zordur.

Avrupa kelimesinin ifade ettiği anlam veya anlamlar sadece bu kıta için değil, iyi ya da kötü; olumlu ya da

başlıklı, 2016 tarihli yayınlanmamış yüksek lisans tezine dayanmaktadır.

${ }^{1}$ Bkz. Gladitor Filmi, Yönetmen: RidleyScott, Dreamworks Pictures ve Universal Pictures yapımı, ABD 2000. 
olumsuz neredeyse bütün dünya için geçerlilik kazanmış bir değerler dizisi olmuştur. $\mathrm{AB}$ ise, uluslararası siyasette yeni bir aktör olarak ortaya çıkmış ve ulusüstü (supranasyonel) özelliği ile suigeneris bir kurum haline gelmiştir. Bir yandan ulus devletlerin birlikteliği ve egemenlik devri konusu, diğer yandan AB'nin kurumları, bu kurumların oluşum ve işleyişleri ve nihayetinde $A B$ 'nin günümüzde sahip olduğu coğrafi ölçek düşünürleri, akademisyenleri, araştırmacıları ve stratejistleri $\mathrm{AB}$ üzerine daha fazla düşünmeye ve çalışmaya sevk etmektedir. AB, bir yandan yerleşik demokrasilerin büyük çoğunluğuna ev sahipliği yapmaktadır diğer yandan da tüm kıtayı kapsayan dev ölçekli bir demokrasi olmayı hedeflemektedir. Yerleşik ve gelişmiş demokrasiler, Avrupa'nın özellikle kuzeybat1 bölümünde yoğunlaşmaktadır. AB sınırlarını kapsayan bir demokrasi modeliyse ölçek bakımından üzerinde uzunca düşünmeyi gerektirecek bir boyuta sahiptir. Diğer yandan günümüzde demokrasi kavramı en genel haliyle, siyasi partilerin parlamentoları ve hükümeti seçimler yoluyla oluşturduğu bir mekanizma olmaya indirgenmiş bulunmaktadır. En bilinen ve genel kabul gören demokrasi araçları bunlardır. Bu sebepten dolayı siyasi partiler, demokratik siyasi yaşamın temel yapı taşı olarak nitelendirilmekte ve değerlendirme ölçütlerinde seçimlerin özelliklerine önem verilmektedir. Modern demokrasilerin bu üç kavramı daAB'nin gelişiminde önemli konu başlıkları olarak ortaya çıkmaktadır.

AB kapsamında siyaset bilimi bakımından ilginç konulardan biri de, Avrupa Parlamentosu (AP) ve burada yer alan siyasi gruplardır. Siyasi gruplar, parlamentoda farklı ülkelerden gelen benzer eğilimli parlamenterleri bir araya getirmektedir. Aynı zamanda söz konusu bu gruplar, ulusal partilerin bir araya geldiği bir çatı olma işlevini de görmektedir. AP siyasi gruplarının anlaşılması, demokrasi, siyasi parti ve seçim kavramlarıyla olduğu kadar $A B$ projesiyle de yakından ilgilidir. Ayrıca yakın gelecekte demokrasinin ve AB'nin seyri bu siyasi grupların durumuyla da orantıli olacaktır.

$\mathrm{Bu}$ makale, genel olarak AP siyasi gruplarını ele almakta ve yukarıda bahsi geçen kavramsal çerçeve üzerine kurulmaktadır. AP'de yer alan bu siyasi grupların siyasi partiler literatüründeki ve AB'nin gelişimindeki yerlerinin oldukça önemli ancak ülkemizde yeterince tartışma konusu olmayan bir durumda olduğu düşünülmektedir. Oysa küreselleşme ve Avrupa kıtası çapındaki birlik hareketi muhtemelen siyaset bilimi ve uluslararası ilişkiler disiplinlerinin de bakış açılarını değiştirmekte ve yenilemektedir. Hal böyle olunca konunun özgün yanı da ön plana çıkmaktadır. Makalenin üzerine odaklandığı ana araştırma sorusu, Avrupa Parlamentosu'ndaki siyasi grupların işlevinin, konumunun ve politikalarının neler olduğu ve bu açıdan grupların birbirine göre politika konum ve politikalarının farklılıklarının neler olduğudur. Avrupa Parlamentosu siyasi grupları da sağ - sol siyasi yelpazesine ve/veya yeni toplumsal hareketler ve ideoloji ötesi konular çerçevesinde dağılmış politik tercihlere ve konumsal yayılıma sahiptirler. Bu tercih ve konumları gereği, öncelikle $\mathrm{AB}$ entegrasyonunu yorumlayarak gerek güncel konu ve sorunlara yönelik gerekse de AB'nin geleceğine yönelik söylem geliştirir, politika üretir, seçim rekabetine girer ve müzakerelerde bulunurlar. Bir yandan bilindik siyasi parti tanım ve ölçeğinin ötesinde bir yapıya sahip olan bu gruplar diğer yandan da temsili demokrasilerin ölçeğini oldukça büyütmektedirler. AP siyasi gruplarını anlamak söz konusu kavramların geleceğini tartışırken de önemli bir boyut sağlayabilir. $\mathrm{Bu}$ makale söz konusu bu gruplara odaklanmakta ve incelemektedir.

\section{Avrupa Parlamentosu ve Siyasal Gruplar}

Avrupa Parlamentosu her ne kadar Avrupa Kömür ve Çelik Topluluğu'ndan gelse de gerçek anlamda Parlamento, üç topluluğun Parlamenter Meclisi'ne dayanmaktadır. Bu isim ilk olarak 1962 yılında dile getirilmiştir. Avrupa Parlamentosu, ulus-üstü bir yapıda kurumsal gelişiminin iyi bir örneğidir. $\mathrm{AB}$ üye sayısının değişimi, diğer $\mathrm{AB}$ kurumlarının değişimi, dış dünya koşullarının değişimi, evrensel kavramlardaki değişiklikler ve birçok faktör, Parlamentoyu da değişime ve yeniliklere yöneltmiştir. Avrupa Parlamentosu'nun ilk seçimleri 7-10 Haziran 1979 tarihinde gerçekleştirilmiştir. $\mathrm{Bu}$ seçimlerle birlikte, atanmışların parlamentosundan seçilmişlerin parlamentosuna geçilmiştir. İlk seçimlerden itibaren üye sayısı artış göstermiştir. 2004 seçimlerinde Parlamentonun üye sayısı 700'den 732'ye çıkarılmıştır. 2007 yılında geçici olarak 785 'e yükselse de 2009 yılından yapılan seçimlerin ardından üye sayıs1 736'ya düşürülmüştür. Lizbon Antlaşması ile Parlamento üye sayısının maksimum 751 olmasina karar verilmiştir. 2010 yılında Hükümetlerarası Konferans'ta imzalanan düzeltme protokolü gereği parlamentoya 18 üye daha atanmıştır. Son olarak 1 Temmuz 2013 tarihinde Hirvatistan'ın AB'ne üye olmasiyla Parlamento'nun maksimum üye sayısı geçici olarak 766 olmuş ve bu sayı 2014 seçimleri için tekrar 751'e düşürülmüştür (TheEuropeanParliament: Historical Background, FactSheets on theEuropeanUnion - 2015; TheEuropeanParliament: TheCitizen's Voice InThe EU, Luxembourg: Publications Office of theEuropeanUnion, 2014).

Tablo 1: Tarihsel Süreçte Sayılarla Avrupa Parlamentosu

\begin{tabular}{|c|c|c|c|c|c|c|c|c|}
\hline & $\mathbf{1 9 7 9}$ & $\mathbf{1 9 8 4}$ & $\mathbf{1 9 8 9}$ & $\mathbf{1 9 9 4}$ & $\mathbf{1 9 9 9}$ & $\mathbf{2 0 0 4}$ & $\mathbf{2 0 0 9}$ & $\mathbf{2 0 1 4}$ \\
\hline $\begin{array}{c}\text { Parlamento } \\
\text { Üye Sayısı }\end{array}$ & 410 & 434 & 518 & 567 & 626 & 732 & 736 & 751 \\
\hline $\begin{array}{c}\text { Üye Devlet } \\
\text { Sayısı }\end{array}$ & 9 & 10 & 12 & 12 & 15 & 25 & 27 & 28 \\
\hline $\begin{array}{c}\text { Siyasi Grup } \\
\text { Sayısı }\end{array}$ & 7 & 8 & 10 & 9 & 8 & 7 & 7 & 7 \\
\hline $\begin{array}{c}\text { Ulusal Siyasi } \\
\text { Parti Sayısı }\end{array}$ & 57 & 67 & 103 & 97 & 127 & 168 & 176 & 191 \\
\hline $\begin{array}{c}\text { Siyasi } \\
\text { Gruplardaki } \\
\text { Ulusal Delege } \\
\text { Sayısı }\end{array}$ & 37 & 42 & 64 & 58 & 74 & 109 & 116 & 129 \\
\hline
\end{tabular}

Kaynak: GiulioSabbati, "EuropeanParliament: FactsandFigures", EuropeanParliamenteryResearch Servise, Brifing November 2014, s.4.

Avrupa Parlamentosu ile siyasi partiler de yeni bir boyut kazanmıştır. Siyasi partiler, AP'nin kurulmasından önce de iletişim halinde olsa da AP, siyasi gruplar için fonksiyonel bir forum ortamı olmuştur (Frantescu, 2015: 101-110). AP, siyasi gruplara daha kolay ve daha hızlı bir iletişim olanağı sağlamıştır. Benzer ideolojideki siyasi partilerin aralarındaki farklılıkların azalmasına ve ilişkilerin geliştirilmesine olanak sağlamıştır. İkinci Dünya Savaşı’nın ardından bu işbirlikleri geliştirilerek parti aileleri ortaya çıkmaya başlamıştır. Bu gelişmeler neticesinde ilk Avrupa Parlamentosu seçimlerine doğru kurumsallaşma ve organizasyon açısından önemli derecede ilerleme kaydedilmiştir. Ulusal aktörler, uluslararası sorunların ancak uluslararası işbirliği ile çözülebileceğini görmeye başlamışlardır (Köktaş, 2002: 89-108).16 Haziran 1953 tarihinde Ortak Meclis'te yapılan oylama neticesinde siyasi gruplar usul kuralları ile resmiyet kazanmıştır. İlk aşamada üç grup kurulmuştur: Sosyalistler, Hiristiyan 
Demokratlar ve Liberaller(Bressanell, 2010: 2-3). 1965 ve 1973 yılları arasında ise bu gruplara Muhafazakârlar, Komunistler ve Gaulistler de dâhil olmuşlardır. İlk seçimlerden itibaren yavaş yavaş ulusal parlamentolarda temsil edilmeyen siyasi hareketler de ortaya çıkmaya başlamıştır.

Grup politikaları konusunda "oy иуumu” olarak ifade edilebilecek grup içi bağlılık zamanla artış göstermiştir (McElroy\& Benoit, 2007: 5-28). Ulusal partiler, kendi ideolojilerine uygun olarak kendilerine göre Avrupa çıkarları için daha sıkı işbirliği içine girmeye başlamışlardır. Avrupalılık bilinci, siyasi partilerin de Avrupalılaşmasında pekiştirici rol oynamıştır (http://www.cvce.eu). 1979 yılı öncesinde altı olan siyasi grup sayısı 2015 yılı itibari ile sekizdir. Siyasi grup sayısının artmamasının nedenleri çeşitlidir. Yeni üyeler, Parlamento’ya geldiklerinde mevcut gruplara katılmayı tercih etmektedirler. Üyeler, çok uluslu bir yapıda yeni bir siyasi hareket riskine girmektense kurumsallaşmış bir gruba üye olarak statü kazanmayı tercih etmişlerdir. Ayrıca, tek ülkeden grup oluşturmanın kısıtlanması, gruplarda üye ülkelerin en az beşte birinin temsil edilmesi ve en az 20 üyeye sahip olması gibi Avrupa Parlamentosu usul kuralları'nın gereklilikleri, grup sayısının artmasına engel olmaktadır. $\mathrm{Bu}$ nedenlere bağlı olarak Avrupa Demokratik Birliği Grubu (EuropeanDemocraticUnionGroup, UDE), Avrupa Sağ1 (European Right, ER), Gökkuşağı Grubu (RainbowGroup), Bağımsız Üyelerin Teknik Grubu (Technical Group of IndependentMembers, TDI) kalıc1 gruplar olmayı başaramamışlardır (BuildingParliament: 50 Years of EuropeanParliamentHistory 1958-2008, 2009).

Siyasi gruplar, parlamentonun belkemiğini oluşturmaktadır. Avrupa Parlamentosu, bütün bölgesel ve uluslararası devlet ve kuruluşlar arasında gerçek anlamda ulus-üstü karaktere sahip olan tek kurumdur. Avrupa Parlamentosu siyasi grupları; Parlamento'nun siyasi yetkileri, onların AB Dış politikasındaki retorik rolü ve üçüncü ülkeler ile diplomatik ilişkiler açısından önemlidir. Ülkeler arasında karşılıklı anlayışın geliştirilmesinde ve hükümetler ile temsilcilerin yönlendirilmesinde siyasi grupların rolü büyüktür. Amsterdam Antlaşması'nda Avrupa partilerinin konumu şu şekilde açıklanmıştır (Köktaş, 2002: 14): “Avrupa düzeyinde siyasi partiler Birlik'te bütünleşme faktörü olarak önemlidir. Bu partiler Avrupa bilincinin oluşturulmasına ve Birlik yurttaşlarının siyasi iradesini seslendirmeye katkıda bulunurlar." Siyasi grupların esas önemine vurgu yapıldığ bir başka yer ise, AB Antlaşması madde 191'dir: "Avrupa düzeyinde siyasi partiler, Birlik içindeki entegrasyon için bir faktör olarak önemlidir. Onlar Avrupa bilincini oluşturmaya ve Birlik vatandaşlarının siyasi iradesinin ifade edilmesine katkıda bulunurlar." Siyasi gruplar, AB vatandaşları ile AB Kurumları arasında köprü görevi yürütmektedir. Özellikle 2009 yılında Lizbon Antlaşması ile kırkın üzerinde politika alanında ortak karar alma yetkisinin tanınmasıyla Parlamento ve bünyesindeki siyasi gruplar daha fazla önem kazanmıştır. Siyasi gruplar, Ortak Dış ve Güvenlik Politikası'nda önemli etkisi bulunan AP diplomasisinde yasama, retorik ve aktif rol oynamaktadır (Vaughne, 2014). Siyasi grupların bir diğer önemi ise, Avrupa Parlamentosu gündeminin belirlenmesinde önemli aktörler olmalarıdır (Hix et al., 2006: 493-520).

Avrupa Parlamentosu'nda, ulusal parlamentolarda olduğu gibi, bir grubun üyesi olmadan bağımsız olarak rol üstlenen üyeler bulunmaktadır. Fakat bağımsız üyeler, grup üyeleri gibi, Parlamento'nun siyasi ve örgütsel yapılarında önemli pozisyonlara gelememektedir. Siyasi grup olmanın bir diğer avantaj1 ise, grup üyelerinin bağımsız üyelere nazaran daha fazla ekonomik kaynağa sahip olmalarıdır (Poptcheva, 2015: 1). Bu açılardan da siyasi grupların öneminin yanında siyasi gruplara üye olmanın önemi anlaşılmaktadır. Grup disiplini içerisinde üyeler, Parlamento sürecine daha etkili katkı sağlayabilmektedirler.

\section{Siyasi Grupların İşleyişi}

Parlamento üyeleri, parlamentoda siyasi gruplar halinde oturmaktadırlar. Milliyetçilik sınırları aşarak ulus üstü bir birlik kurma başarısını gösteren AB'nin temsil organı olan Parlamento'da doğal olarak bu gruplar milliyet çerçevesinde değil, siyasi görüş çerçevesinde oluşturulmaktadır. AP siyasi gruplarının ulusal parlamentolardan önemli bir fark1 vardır. Bir takım siyasi topluluklar arasında içinde değişik görüşlerde topluluklarda da beraber var olabilir. Örneğin bir dönem Avrupa Halk Partisi ve Avrupalı Demokratlar Grubu içinde hem AB'nde bütünleşmeye sıcak bakan Hristiyan Demokratlar, hem de daha fazla bütünleşmeye şüpheyle yaklaşan İngiliz Muhafazakârlar yer alabilmiştir. Uluslar Avrupası için Birlik Grubu içinde de hem İrlanda'nın 1lımlı partisi FiannaFail'e, hem de faşizme yakın görüşleriyle bilinen İtalya'nın Ulusal İttifak Partisine rastlamak mümkündür (http://www.bbc.co.uk).

Parlamento üyeleri genel olarak üyesi olduğu siyasi grubun görüşleri doğrultusunda hareket etmekle birlikte bazı istisnai durum ve koşullarda ulusal, bölgesel ve sektörel çıkarları doğrultusunda hareket edebilmektedir (Jacobs\& Best, 2004: 14-19). Bu konuda grup alışkanlıklarından da bahsedilebilir. Örneğin, Avrupa Halk Partisi; ekonomi, kaynakların dağılımı, iç pazar, uluslararası ticaret, bütçe, tarım gibi politika alanlarında genel olarak ortak bir yaklaşım sergilerken, etnik konularda üyeler özgür iradelerini ortaya koyabilirler. AP'nin ikinci büyük grubu S\&D'de ise özgürlükler ve sosyal konularda ortak yaklaşım dikkati çekerken üyeler ekonomi ve tarım politikalarında daha özgür karar verebilmektedirler (Frantescu, 2015: 101-110). Bu durum, grup içi demokrasinin gelişmişliğinin bir göstergesi olarak algilanabilir. Avrupa Parlamentosu'nda ortak Avrupa çıkarları ön planda olduğu dikkate alındığında, bu durumun ulusal düzeyden farklı değerlendirilmesi gerekliliği ortaya çıkmaktadır.

Siyasi gruplar ile ulusal partiler politika değişkenliği açısından kıyaslandığında, siyasi grupların daha statik, ulusal partilerin ise daha değişken olduğu görülmektedir (McElroy\& Benoit, 2007: 5). Siyasi grupların pozisyonlarının statik olmasının temelinde grubun genel bir eğilimi olması ve bu eğilime göre ulusal partilerin gruba dâhil olması yatmaktadır. Yani, siyasi grupların pozisyonlarındaki bir değişiklikte grup içinde değişimler yaşanması muhtemel bir durumdur.

Siyasi gruplar ile ulusal partiler, siyasal temsil açısından kıyaslandığında ise ulusal partilerin daha etkin olduğu görülmektedir. Bunun temel nedenleri arasında seçmenlerin ulusal düzeyde seçimlere daha ilgili ve politika alanlarına daha hâkim olması, Avrupa düzeyinde yapılan seçimlerde de baş aktörün yine ulusal partiler olması ve genel olarak ulusal sorunların siyasi malzeme olarak kullanılması yer almaktadır (Costello et al., 2012: 1229). Ulus-üstü düzeyde siyasi temsilin Avrupa'da tek olması ise onu emsali ile kıyaslama 
yapmaya müsaade etmemektedir. Yani siyasi gruplar ile ulusal partileri kıyaslamak, farklı kategorilerde olduğundan kıyaslama yapmak yerine ilişkileri ortaya koymak daha doğrudur.

Siyasi gruplar parlamenter sayılarına göre $\mathrm{AB}$ bütçesinden aldıkları kendilerine ait bütçeleri, yönetim yapılanması, usul kuralları ve liderlik yapıları ile üst düzey kurumsallaşmış yapılardır. Her siyasi grubun bir başkanı vardır ve sekretaryaları tarafından günlük çalışmalar yapılmaktadır. Ayrıca sekretaryaların uzmanlık alanlarına göre danışmanları bulunmaktadır. Sekretaryaların, uluslararası olaylara odaklı bölümleri vardır. Komiteler ve delegeler sayesinde grup politikaları yönlendirilmekte ve yürütülmektedir. Kalıcı veya geçici, genel veya özel nitelikte bu komitelerin görev alanları parlamento tarafından belirlenmektedir. Komiteler genel oturumlarda parlamentonun kabul edeceği kararları hazırlamaktadır. Komisyon teklifleri üzerine Konsey'in almış olduğu kararlar, ilgili komiteler tarafindan incelenip, parlamentoya rapor edilmektedir (Akçadağ, 3).

Parlamento genel kurul toplantıları ve basın konuşmaları dışında siyasi gruplar, haftalık grup içi toplantılar, komiteler ve alt komiteler ile çalışmalarını yürütmekte ve görüşlerini duyurmayı başarmaktadır. Grup içi toplantılar, siyasi grubun benimsediği hususların tartışıldığı platformlardır. Genel kurul toplantılarında ise komiteler tarafindan hazırlanan raporlar analiz edilerek siyasi gruplar bunlara yönelik tavırlarını ortaya koyar. Grup içi toplantıların ana merkezi ise gruba stratejik ve politik yön veren Büro toplantılarıdır. Bürolar; grup başkanları, ulusal delege liderleri, gruba bağlı komite başkanları ve sayıları gruba göre değişen seçilmiş AP üyelerinden oluşmaktadır. Büro toplantıları, ayda 2-3 kez düzenli olarak yapılmaktadır. Komiteler ise farklı gruplardan parlamento üyelerinin ortak yasa tasarısı ve tasarı raporlar hazırlandığı ve uzmanlar tarafından çalışmaların yürütüldüğü kurumsal organlardır. Siyasi gruplar, Avrupa Parlamentosu'nun 20 komitesi ve iki alt komitesinin her biri için bir koordinatör atar. Gruplarının görüşlerini ortaya koyan komite koordinatörlerinin yasama sürecinde rolü büyüktür (www.politico.eu).

Ulusal partiler, oy kullanma, siyasaların temsili ve seçim kampanyalarının yürütülmesi gibi faaliyetleri hem ulusal parti olarak hem de Avrupa Parlamentosu'nun bir parçası olarak yürütürler. Partiler arasında ayrılık klasik sağ-sol ayrımına ve $\mathrm{AB}$ konularındaki görüş farklılıklarına dayanmaktadır (McElroy\& Benoit, 2015: 1-22).

Siyasi grupların oluşum, işleyiş ve geleceğini etkileyen faktörlerin başında AB'nin genişlemesi gelmektedir. Genişleme süreci, siyasi grupların ve Avrupa partilerinin geleceği açısından önemlidir.Yapılan araştırmalar (Jacobs\& Best, 2004: 14-19), büyük gruplar arasında grup içi bağlılığın daha yüksek olduğunu göstermektedir. Dolayısıyla, genişleme süreci ile birlikte siyasi grupların üye sayısında ve etnik çeşitliliğinde artış ile coğrafi difüzyonu dikkate alındığında, genişlemenin büyüyen gruplara pozitif, diğer gruplara ise negatif sonuçları olabileceği değerlendirilmektedir. $\mathrm{Bu}$ açıdan bakıldığında, aday ülkelerdeki siyasi eğilimlerin, siyasi grupların aday ülkeye bakış açısını dolaylı olarak etkilemesi mümkün gözükmektedir. AB'nin genişlemesi ile birlikte Avrupa Parlamentosu'nun AB içerisindeki rolü ve konumu, AP'nin gücünün arttırılması, AP içerisinde ve üye devletlerde siyasi grupların formal ve informal olarak niteliksel ve niceliksel büyümesi siyasi grupların geleceğinde önem taşımaktadır.

\section{Siyasi Gruplar ve Ayırt Edilen Güncel Politikaları}

Avrupa vatandaşları, Avrupa Parlamentosu seçimlerinde tercihleri ile dolaylı olarak ve ulusal seçimlerde ise doğrudan AB'nin şekillenmesini etkilemektedirler. Bu açıdan Avrupa vatandaşları ve seçimler önemli olmakla birlikte ulusal partilerden oluşan siyasi grupların genel Avrupa sorunlarına karşı seçmenlere politika seçenekleri sunması, seçmenlerin performans açısından geçmişe yönelik değerlendirme ile politikaları açısından ileriye yönelik değerlendirme yaparak tercihini ortaya koyması sonucu vatandaşlar AP'de politika yapma sürecine katkı sağlamaktadır (Marsh\&Norris, 1997: 154). 2014 seçimleri ile birlikte Parlamento'da ortaya çıkan kompozisyonda sekiz grup bulunmaktadır. $\mathrm{Bu}$ seçimlere katılım oranı \%42,61 olmuştur. Öte taraftan 2014 seçimleri, AB karşıtı olan aşırı sağcı grupların zaferi ile sonuçlanmıştır. 2014 y1lı seçimleri sonucunda siyasi grup temsilcilerinin ülkelere dağılımı şu şekildedir;

Tablo 2: Siyasi Grup Üyelerinin Uluslara Göre Dağılımı

\begin{tabular}{|c|c|c|c|c|c|c|c|c|c|c|}
\hline ÜLKE/YIL & & & & & & & & & III & $\sum$ \\
\hline Almanya & 34 & 27 & 6 & 4 & 8 & 13 & 1 & 1 & 2 & 96 \\
\hline Avusturya & 5 & 5 & & 1 & & 3 & & 4 & & 18 \\
\hline Belçika & 4 & 4 & 4 & 6 & & 2 & & 1 & & 21 \\
\hline $\begin{array}{l}\text { Birleşik } \\
\text { Krallık }\end{array}$ & & 20 & $\begin{array}{l}2 \\
1\end{array}$ & 1 & 1 & 6 & 20 & 1 & 3 & 73 \\
\hline Bulgaristan & 7 & 4 & 2 & 4 & & & & & & 17 \\
\hline $\begin{array}{l}\text { Çek } \\
\text { Cumhuriyet }\end{array}$ & 7 & 4 & 2 & 4 & 3 & & 1 & & & 21 \\
\hline Danimarka & 1 & 3 & 4 & 3 & 1 & 1 & & & & 13 \\
\hline Estonya & 1 & 1 & & 3 & & 1 & & & & 6 \\
\hline Finlandiya & 3 & 2 & 2 & 4 & 1 & 1 & & & & 13 \\
\hline Fransa & 20 & 13 & & 7 & 4 & 6 & 1 & 20 & 3 & 74 \\
\hline Güney Kıbrıs & 1 & 2 & 1 & & 2 & & & & & 6 \\
\hline Hirvatistan & 5 & 2 & 1 & 2 & & 1 & & & & 11 \\
\hline Hollanda & 5 & 3 & 2 & 7 & 3 & 2 & & 4 & & 26 \\
\hline İrlanda & 4 & 1 & 1 & 1 & 4 & & & & & 11 \\
\hline İspanya & 17 & 14 & & 8 & 11 & 4 & & & & 54 \\
\hline İsveç & 4 & 6 & & 3 & 1 & 4 & 2 & & & 20 \\
\hline İtalya & 15 & 30 & 2 & & 3 & 1 & 15 & 6 & 1 & 73 \\
\hline Letonya & 4 & 1 & 1 & 1 & & 1 & & & & 8 \\
\hline Litvanya & 3 & 2 & 1 & 3 & & 1 & 1 & & & 11 \\
\hline Lüksemburg & 3 & 1 & & 1 & & 1 & & & & 6 \\
\hline Macaristan & 12 & 4 & & & & 2 & & & 3 & 21 \\
\hline Malta & 3 & 3 & & & & & & & & 6 \\
\hline
\end{tabular}




\begin{tabular}{|c|c|c|c|c|c|c|c|c|c|c|}
\hline Polonya & 23 & 5 & $\begin{array}{l}1 \\
9\end{array}$ & & & & 1 & 2 & 1 & 51 \\
\hline Portekiz & 8 & 8 & & 1 & 4 & & & & & 21 \\
\hline Romanya & 12 & 15 & 1 & 3 & & & & 1 & & 32 \\
\hline Slovakya & 6 & 4 & 3 & & & & & & & 13 \\
\hline Slovenya & 5 & 1 & & 1 & & 1 & & & & 8 \\
\hline Yunanistan & 5 & 4 & 1 & & 6 & & & & 5 & 21 \\
\hline Toplam & $\begin{array}{c}21 \\
7\end{array}$ & 189 & $\begin{array}{l}7 \\
4\end{array}$ & 68 & 52 & 51 & 42 & 40 & $\begin{array}{l}1 \\
8\end{array}$ & 751 \\
\hline Oy Oranı & $\begin{array}{c}28 \\
, 8 \\
9\end{array}$ & $\begin{array}{c}25,1 \\
7\end{array}$ & $\begin{array}{l}9, \\
8 \\
5\end{array}$ & 9,05 & 6,92 & $\begin{array}{c}6,7 \\
9\end{array}$ & $\begin{array}{c}5,5 \\
9\end{array}$ & 5,33 & $\begin{array}{l}2 \\
\text {, } \\
0\end{array}$ & \\
\hline
\end{tabular}

Kaynak:

http://www.europarl.europa.eu/meps/en/crosstable.html (10.03.2016)

Avrupa Parlamentosu'nda yer alan siyasi grupların, her seçim döneminde kurulan ittifaklara göre değişiklik gösterebilmekle birlikte, genel olarak kalıplamış olduğu da söylenebilir. Bu durum, siyasi grupların kurumsallaşmasının önünü açmakta ve meşruiyetinin artmasını sağlamaktadır. Bressanelli'nin(2012: 13-25)yapmış olduğu araştırmalar ideoloji, pragmatizm ve grubun büyüklüğünün, ulusal partilerin AP'de siyasi grup tercihinde en önemli faktörler olduğunu göstermektedir. Dolayısıyla siyasi grupların ideolojik değişimleri, siyasi grupların kompozisyonlarını ve politikalarını da etkilemektedir. Ayrıca, Bressanelli'nin araştırmaları, ulusal partilerin klasik sağ/sol ideolojilerinin ulus-üstü boyutta farklılaştığını göstermektedir. Dolayısıyla bir siyasi grubu mutlak sağ veya sol partilerin oluşturduğu söylenemez. Siyasi gruplar aynı anda, sağ ve sol kanattan partileri bünyesinde bulundurabilir.

\section{a. Avrupa Halk Partisi Grubu (EPP)}

Avrupa Halk Partisi (EPP) grubu; 1lımlı merkez Hristiyan demokrat ve demokrat Avrupa partilerinden oluşan Avrupa Parlamentosunun en büyük grubudur (Bressanelli, 2012: 1325).Hristiyan Demokrat ve muhafazakâr 1lımlı sağ partilerin oluşturduğu bir çatı olarak görülen ve kendisini Avrupa kıtasının tarihinden ve medeniyetinden gelen merkez sağ partiler ailesi olarak tanımlayan EPP'nin ideolojik yapısında; Hristiyan demokrasi, liberal ve muhafazakâr politikalar öne çıkmaktadır (Kiriş, 2013: 127). Merkez sağ çizgide olan ve 1976 yılında kurulan EPP; AB vatandaşlarına yakın olmayı, sosyal piyasa ekonomisini ve daha rekabetçi ve demokratik bir Avrupa hedefleyen merkez ve merkez-sağ güçlerin grubudur. EPP Grubu, federal modele dayalı güçlü bir Avrupa fikrinin savunucusu olmakla birlikte ideolojik açıdan geleneksel muhafazakâr parti tipolojisine uygun değerleri desteklemektedir (Demirel, 2014: 143-148).1976 yılında Belçika Parlamentosu üyesi LeoTindemans başkanlığında resmi olarak kurulan EPP, 1978 yılında aynı ismin Avrupa partisi ile bağlantısını işaret etmek maksadıyla "Hristiyan Demokrat Grup" olarak değiştirilmiştir. 1979 yılında, ilk seçimler boyunca, "Avrupa Parlamentosu Hristiyan Demokratik Grubu" adını kullanmıştır. Karar mekanizmasında etkin rol oynamak isteyen parti, benzer düşüncede olan muhafazakârlar ile işbirliği kararı almıştır. 1999 yılında, EPP ve Avrupa Demokratları olmuştur. 2002 yılında, Muhafazakârlar ile birleşme gerçekleşmiştir
(www.epp.eu).Avrupa Halk Partisi, Avrupa bütünleșme sürecinin başlangıcından itibaren Parlamento'nun önemli bir grubu olmuştur. Entegrasyon sürecinde önemli rol üstlenen Robert Schuman, Alcide de Gasperi ve Konrad Adenauer bu ailedendir (www.EPPgroup.eu).

EPP gerek entegrasyon sürecinde gerekse sonrasında birleşik bir Avrupayı savunurken, Avrupa'nın ve Avrupalıların ortak menfaatlerinin teminini sağlayacak bir gelecek için birincil ilke olarak hukuk ve temel hakları ve ikincil ilke olarak da gücün etkili bir şekilde paylaşılması ve bağımsız demokratik kurumların inşasını, zengin iç pazarın oluşturulmasını öncelikli hedef kabul ettiğini ifade etmektedir (www.EPPgroup.eu). Ortak dış ve güvenlik politikasında sürekliliğin sağlanmasını ve verimliliğin arttırılmasını arzu etmektedir (Demirel, 2014: 143-148).

2003 yılında yürürlüğe giren ve 2007 y1lında revize edilen AB Avrupa Düzeyinde Siyasi Partileri ve Kuruluşlarına Dair Kurallar Üzerine Düzenleme (www.epp.eu) esaslarına göre yönetilmektedir.EPP'nin dört alanda politika önceliğinin bulunduğu görülmektedir. Bunlar (www.epp.eu); ekonomik iyileşme ve iş istihdamı; özgürlük, güvenlik ve adalet; Avrupa sosyal modeli; AB'nin küresel aktör olarak görevleridir. Ayrıca EPP'nin ekonomi alanında dört önceliği arasında yer alan ekonomik iyileşme ve iş istihdamı kapsamında atılması gereken adımlar, sosyal piyasa ekonomisini gerçekleştirme, istikrar, büyüme, tek pazar ve enerji üzerine kurulmuştur. Özgürlük, güvenlik ve adalet alanında EPP; göçmenlik konusunda komiser atanmasını, AB sınırlarının güvenliğinin maksimum düzeye çıkarılmasını, siber güvenlik politikalarının geliştirilmesini gerekli görmektedir. EPP, AB'nin kültürel boyutuna özel önem gösterilmesi gerektiğini de savunmaktadır. AB'nin küresel rolünü güçlendirmek için diş politikada temel değerler göz önünde bulundurularak ortak tavir sergilenmelidir. EPP'nin Ukrayna politikasında, Ukrayna-Rusya ilişkilerinde Ukrayna'ya verilen desteğin arttırılmasından ve barışçıl bir çözümden yana olduğu görülmektedir (www.euractiv.com).Türkiye'nin AB'ye üyeliği EPP içerisinde görüş ayrılıklarına sebep olmuştur. Örneğin Almanya Şansölyesi Merkel, Türkiye'nin üyeliğine karşıtlığı ile dikkat çekerken, az da olsa Türkiye'nin üyeliğini destekleyen bir kısım bulunmaktadır. Genel olarak, grup içerisinde Türkiye'nin üyeliğine karşı negatif bir yaklaşım olduğunu söylemek mümkündür (www.dw.com). Bir küresel güç olarak AB'nin, Milenyum Kalkınma Hedeflerinin uygulayıcısı ve takipçisi olması gerektiğini savunan EPP'ye göre $A B$ ve üye devletler Milenyum Kalkınma Hedeflerine sadık kalmalıdırlar.

\section{b. Sosyalist ve Demokratların İlerici İttifakı Grubu (S\&D))}

Sosyalist ve Demokratların İlerici İttifakı Grubu (S\&D), sosyal demokrat ve işçi partilerinin bir araya geldiği AP'nin ikinci büyük grubudur. ${ }^{2} 2014$ seçimleri sonucunda S\&D,

${ }^{2}$ S\&D’ye üye olan partiler şöyle sıralanabilir: Avusturya, SozialdemokratischeParteiÖsterreichs; Belçika, Parti Socialiste, SocialistischePartijAnders;

Bulgarskasotsialisticheskapartiya; Bulgaristan, Hirvatistan,

SocijaldemokratskapartijaHrvatske; Güney Kıbrıs Rum Yönetimi, KinimaSosialdimokraton EDEK, DimokratikóKómma; Çek Cumhuriyeti, Českástranasociálnědemokratická; Danimarka, Socialdemokraterne; Estonya, SotsiaaldemokraatlikErakond; Finlandiya, SuomenSosialidemokraattinenPuolue; Fransa, Parti 
Parlamento'da 191 Parlamento üyesi ile temsil edilmektedir. S\&D, Avrupa Sosyalist Partisi ve sol eğilimli demokratların işbirliğinden oluşmaktadır. Avrupa düzeyindeki tüm sosyalistler, sosyal demokratlar ve isçi partileri S\&D Grubunun bünyesinde yer almaktadır. Bu işbirliğinin önemli bir bölümünü Alman sosyal demokratlar, İspanyol sosyalist işçi partisi, Fransız sosyalist parti, İtalyan demokrat parti ve İngiliz işçi partisi mensubu üyeleri oluşturmaktadır (www.siyasaliletisim.org).

Avrupa Sosyalist Partisi resmi olarak 1992 y1lında partinin bu isimle kurulmasıyla başlasa da Avrupadüzeyinde sosyalistler grubunun tarihi Avrupa Kömür Çelik Topluluğu'nun kurulma sürecine kadar gitmektedir. 1952'de kurucu altı ülkenin ulusal sosyalist partileri Avrupa Kömür Çelik Topluluğu Ortak Assamblesi'nde Sosyalist Grubu kurmuşlardır. 1957 yılında Sosyalist Partiler Bürosu kurulmuştur.1960'larda, nihai olarak bir Avrupa Birleşik Devletleri hedefleyen sosyalistler, milliyetçi akımın yarattığ 1 atmosfer karşısında zor durumda kalmıştır. 1970'lerde Sosyal Bir Avrupa'ya Doğru programını açıklayan sosyalistler, Avrupa entegrasyonunda fikri olarak ayrılık göstermiş ve bunun neticesinde ortak bir seçim deklarasyonu oluşturmaya çalışmışlardır. 1975 yılında daha önceden kriz nedeniyle katılımı reddeden İşçi Partisi üyelerinin katılımıyla Parlamento'nun en büyük grubu olmuştur. 1980'ler ise, Sosyalist PartilerinKonfederasyonu'nda liderlerin öncelikli politikalar üzerinde çalıştıkları bir dönem olmuştur. 1992 yılında AB Kurucu Antlaşması'nın getirdiği düzenlemeyle Avrupa Sosyalistleri Partisi resmen kurulmuştur. 1993 yılında "Avrupa Sosyalistleri Parti Grubu" olarak adını değiştirmiştir. 2004 yılında ise ismi Avrupa Parlamentosu Sosyalist Grubu olarak değiştirilmiştir. Uzun yıllar boyunca grubun kompozisyonu sabit kalmıştır. 2002 yılında, yeni genişleme dalgalarına hazırlık olarak aday ülkelerden gruba ortaklar almak maksadiyla WillyBrandt Programı geliştirilmiştir (BuildingParliament: 50 Years of EuropeanParliamentHistory 1958-2008, 2009: 54).

Önceliklerinin istihdam, dış ve güvenlik politikaları, çevre, demokrasi ve birlik vatandaşlığı, hoşgörü, genişleme ve bütçe olduğunu ifade etmişlerdir. 1993'teki manifesto ile asgari ücretin iyileştirilmesi, asgari çalışma şartlarının sağlanması, kadın-erkek eşitliğinin sağlanması, çevrenin ve tüketicinin korunması, güvenliğin ve barışın işbirliğiyle sağlanması, organize suçlarla mücadele edilmesi, Avrupa vatandaşlarının karar alma süreçlerine katılmasını içererek sosyalistlerin eylem planını belirlemiştir (Kiriş, 2013: 127129).

socialiste; Almanya, SozialdemokratischeParteiDeutschlands

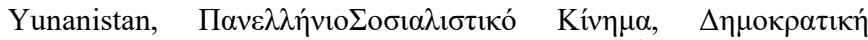

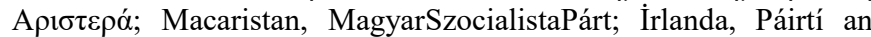
LuchtOibre; İtalya, PartitoDemocratico, PartitoSocialistaItaliano; Litvanya, Lietuvossocialdemokratųpartija; Lüksemburg, LëtzebuergerSozialisteschAarbechterpartei; Malta, PartitLaburista; Hollanda, Partijvan de Arbeid; Polonya, SojuszLewicyDemokratycznej-UniaPracy, SocjaldemokracjaPolska; Portekiz, PartidoSocialista; Romanya, PartidulSocialDemocrat; Slovakya, Smer-sociálnademokracia; Slovenya, Socialnidemokrati; İspanya, PartidoSocialistaObreroEspañol; İsveç, Sverigessocialdemokratiskaarbetareparti; Birleşik Krallık, LabourParty, EuropeanParliamentelections 2014 - list of politicalgroupsandparties

http://en.europewewant.eu/files/2014/04/EP-political-groups-andparties.pdf,(Son Erişim Tarihi:13.02.2016).
2014 yılında yapılan Avrupa Parlamentosu seçimlerinde S\&D tarafından vurgu yapılan konular ise şunlardır; sağlık politikalarını, Avrupa politikalarının merkezine almak, sinsel ve üreme ile ilgili haklarının engellenmemesi, politika yapma sürecine toplumun da dâhil edilmesi, Avrupa kurumları ile vatandaşlar arasında köprülerin güçlendirilmesi, insan haklarının, çocuk haklarının ve sosyal hakların koruma altına alınması, çevre standartlarının yükseltilmesi, kurumsal sosyal sorumluluk (www.socialistsanddemocrats.eu).S\&D'nin politika önceliğinin bulunduğu alanlar sosyal adalet, Temel Haklar Şartı'nın gerçekten uygulanması, iş istihdamı ve büyüme, tüketici hakları, çevrenin daimi korunması, sürdürülebilir gelişme, finansal piyasa reformu, Avrupa vatandaşlarının refah içinde yaşayabileceği daha güçlü ve demokratik Avrupa için mücadele etmektedir. S\&D Grubu'nun politikaları sağ kanat politikaları kemer sıkma nedeniyle eleştirdikleri için dengeli bütçe oluşturulmasını önermeleri, RobinHood vergi sistemini savunmaları, sosyal olarak daha adil bir Avrupa söylemi etrafında emek, gençlik, eğitim, sağlık odaklı politikalara öncelik vermeleridir (www.socialistsanddemocrats.eu).

Eşitlik, S\&D Grubu politikaları arasında mihenk taşıdır. Eşitlik denince son dönemde akla ilk gelen cinsiyet eşitliği gelmektedir. S\&D Grubu, Avrupa vatandaşların demokratik sürece katılımının destekçisi ve teşvik edicisi rolünü üstlenmektedir. Temel haklara ve göçmenlerin haysiyetine saygıl1, çok kültürlülüğün savunucusu olan Avrupa; yasal göçlere pozitif bir yaklaşım sergilemelidir. $A B$ ve ulusal düzeyde bütünleştirici önlemlerin alınması, Avrupa'nın çıkarına olacaktır. S\&D Grubu, AB kurumlarının şeffaflığının ve demokratik sorumluluğun güçlendirilmesinden yana tavır sergilemektedir (www.socialistsanddemocrats.eu).S\&D Grubu'nun dış politikada önceliği, hiçbir ülkenin tek başına güçlü olmadığ yedi milyar nüfuslu değişen dünyada, tek sesli güçlü ve birleşmiş bir Avrupa'nın varolabileceğidir (www.socialistsanddemocrats.eu).

\section{c. Avrupa Muhafazakâr ve Reformcular İttifakı (ECR)}

2003 yılında Çek Medeni Demokratik Partisi (ODS), Polonya Hukuk ve Adalet Partisi ve Muhafazakâr Parti'nin daha fazla Avrupa merkezileşmesine ortak bildiri ile karş1 çıktıklarını açıklamasıyla Avrupa Muhafazakâr ve Reformcular Grubu'nun temelleri oluşmaya başlamıştır. ${ }^{3} 2006$ yılında Çek Medeni Demokratik Partisi ve Muhafazakâr Parti, bu çerçevede Avrupa Reform Hareketi'ni başlatmıştır. 2009 yılının Mart ayında ise Çek Medeni Demokratik Partisi, Muhafazakâr Parti (Birleşik Krallık), Polonya Hukuk ve Adalet Partisi,LijstDedecker (Belçika), Düzen, Hukuk ve Adalet Partisi (Bulgaristan),TB/LNNK (Letonya) Prag Deklarasyonu ve Prensiplerini imzalamıştır

${ }^{3}$ ECR'ye üye olan partiler şöyle sıralanabilir: Belçika, Libertair, Direct, Democratisch; Hurvatistan, Hrvatskastrankaprava; Çek Cumhuriyeti, Občanskádemokratickástrana; Macaristan, Modern MagyarországMozgalom; İtalya, Conservatori e SocialRiformatori; Letonya, Tēvzemei un Brīvībai/LNNK; Litvanya, Lietuvoslenkųrinkimųakcija; Hollanda, ChristenUnie; Polonya, Prawo i Sprawiedliwość, PolskaRazem; Birleşik Krallık, ConservativeParty, UlsterUnionistParty, Bkz. $\begin{array}{lllll}\text { EuropeanParliamentelections } & 2014 \quad- & \text { list } & \text { of }\end{array}$ politicalgroupsandparties http://en.europewewant.eu/files/2014/04/EP-political-groups-andparties.pdf, (Son Erişim Tarihi:13.02.2016). 
(http://ecrgroup.eu). İttifak içinde Avrupa Muhafazakârlar ve Reformistler İttifakı'nın yanında Avrupa Hristiyan Siyasi Hareketi bulunmaktadır. Ulusal muhafazakâr, ekonomik liberal ve ABentegrasyonuna mesafeli politikalarıyla öne çıkmaktadır. Grubun siyasi hedefleri, serbest ticaretin ve rekabetin desteklendiği, vergilerin düşük tutulduğu, devletler tarafindan müdahale edilmeyen bir ekonomi; ileri demokrasi, yenilenebilir kaynaklar odaklı enerji politikası, aile temelli bir toplum, ulus devlet temelli anti-federalist bir Birlik, NATO temelli güçlü transatlantik ilişkiler, sıkı önlemlere tabi bir göç politikası ve AB işleyişinde şeffaflıktır. 2014 seçimleri sonucunda ECR, 71 Avrupa Parlamenteri çıkarmıştır (www.siyasaliletisim.org). ECR, ulusal bakımdan muhafazakâr, ekonomik açıdan liberal politikaları benimsemektedir. Küçük devlet, düşük vergilendirme, aile ve ulus devletlerin egemenliği, $\mathrm{AB}$ federalizmine karşıt yürüttüğü politikalar temel politikalarıdır.

\section{d. Avrupa Liberal ve Demokratlar İttifakı Grubu (ALDE)}

ALDE, liberal ve liberal demokrat düşüncelerin kendisine yer bulduğu AP'nin üçüncü büyük grubudur. ${ }^{4}$ Bünyesinde merkez sağ ve merkez sol partileri yer almaktadır (www.dw.com).ALDE, çatısı altında toplumdaki siyasi, ekonomik ve diğer alanlarda özgürlük temelli; vatandaşlar ve AB kurumları arasındaki bağı geliştirmeyi hedefleyen partiler bulunmaktadır. 2014 seçimleri sonucunda AP'deki üçüncü büyük gruba sahip olan ALDE, muhafazakâr liberalizm, sosyal liberalizm ve merkeziyetçilik eğilimleri baskın olan bir ittifaktır. Düşünce, konuşma, basın, serbest hareket, din, ticaret başta olmak üzere her alanda özgürlük, demokrasi, hukukun egemenliği, insan hakları, dayanışma gibi liberal ilkeler grubun benimsediği temel değerlerdir. ALDE, bu ilkeler çerçevesinde adil, şeffaf, demokratik, refah içinde ve hesap verebilir, çok renkliliğe ve sesliliğe sahip bir Avrupa ve özgür, adil ve açık bir toplum inşa etmeyi amaçlamaktadır (Demirel, 2014: 144). Bu amaç doğrultusunda "Sizin

${ }^{4}$ ALDE'ye üye olan partiler şöyle sıralanabilir: Avusturya, Neos DasNeueÖsterreichundLiberales Forum; Belçika, Open VlaamseLiberalen en Democraten, MouvementRéformateur; Bulgaristan, NacionalnoDviženieZaStabilnost I Văzhod, DvizhenieZaPrava I Svobodi; Güney Kıbrıs Rum Kesimi,

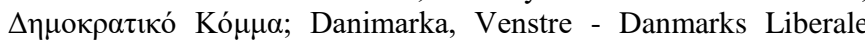
Parti; Estonya, EestiKeskerakond, EestiReformierakond; Finlandiya, SuomenKeskusta, SvenskaFolkpartiet i Finland; Fransa, MouvementDémocrate,Citoyenneté ActionParticipationPour Le 21 éme Siécle, AllianceCitoyennePour La Démocratie En Europe; Almanya, FreieDemokratischePartei; Yunanistan, Drasi; Macaristan, SzabadDemokratákSzövetsége - A MagyarLiberálisPárt; İrlanda, FiannaFáil; İtalya, Democrazia È Libertà - La Margherita, ItaliaDeiValori, Alleanza Per L'Italia, RadicaliItaliani; Letonya, LatvijasPirmāPartija / LatvijasCeḷšs; Litvanya, DarboPartija, LiberalųIrCentroSajunga, LiberalųSąiūdis; Hollanda, VolkspartijVoorVrijheid En Democratie,Democraten 66; Polonya, PartiaDemokratyczna; Romanya, PartidulNaţional Liberal; Slovakya, L’udováStrana - HnutieZaDemokratickéSlovensko; Lüksemburg, DemokrateschPartei; Slovenya, LiberalnaDemokracijaSlovenije, Zares - Socialno-Liberalni; İspanya, ConvergènciaDemocràtica de Catalunya; PartidoNacionalistaVasco; İsveç, FolkpartietLiberalerna, Centerpartiet, FeministisktInitiativ; Birleşik Krallık, Liberal Democrats, Bkz. EuropeanParliamentelections 2014 - list of politicalgroupsandparties

http://en.europewewant.eu/files/2014/04/EP-political-groups-andparties.pdf, (13.02.2016) kaygılarınız bizim kaygılarımızdır. Biz sizin yanınızdayı"” sloganını kullanarak Avrupa vatandaşları ile arasında köprü oluşturmaktadır.

Grubun, Türkiye ile müzakerelerin desteklenmesi ve Türkiye'nin de AB'de yer alması konusunda sergilemiş olduğu pozitif tavır, yasalara uygun şekilde AB'ye gelen göçmenlerin entegrasyonunun sağlanması için gösterdiği çaba, çevresel konulardaki hassasiyeti, insan haklarına saygının dünya çapında sorunsuz olarak işleyişi için attığı adımlar dikkat çekmektedir (www.aldeparty.eu). 2014 yılında yapılan Avrupa Parlamentosu seçimlerinde ALDE tarafından vurgu yapılan konular; iş istihdamının arttırılması, istikrar, daha güçlü ve güvenli bir AB'dir (www.aldeparty.eu). ALDE yeni dönemde kendine 5 öncelikli politika alanı belirlemiştir. Bunlar; insan hakları, yeşil ekonomi, küresel $\mathrm{AB}$, bütçe reformu, büyüme ve iş istihdamıdır (http://www.alde.eu). Temel hak ve özgürlükler, devredilemez niteliğe sahiptir. Güvenlik adı altında kısıtlamalar getirilmesi ALDE değerleri ile bağdaşmamaktadır.

\section{e. Avrupa Birleşik Solu/İskandinav Yeşil Solu Konfederasyon Grubu (GUE/NGL)}

Avrupa Birleşik Solu/İskandinav Yeşil Solu Konfederasyon Grubu (GUE/NGL) ${ }^{5}$, Avrupa projesine karşıt komünist, eko-sosyalist ve demokratik sosyalist sol kanat partilerinden ve Kuzey Yeşil solcularından oluşmaktadır (www.dw.com).GUE/NGL'nin kökeni, 1973 yılında kurulan Komunist ve İttifak Grubu'nadayanmaktadır. AP doğrudan seçimlerinden önce İtalya, Fransa ve Danimarka'dan çeşitli alternatif ve radikal sol partiler, Komünistler ve Müttefikler Grubu adı altında birlikte çalışmışlardır. 1992'de grubun ismi Avrupa Birleşik Solu olarak değiştirilmiştir. 1994'te AP seçimlerinden sonra sosyal olmayan demokrat sol birleşmeye başlamıştır. $\mathrm{Bu}$ birleşme hareketi, dördüncü parlamento döneminde Avrupa Birleşik Solu Konfederal Grubu kurulmasıyla devam etmiştir. AB'ye Kuzey ülkelerinin ve Avusturya'nın da 1995 y1lında katılmasının ardından Grup, Avrupa Birleşik Solu/İskandinav Yeşil Solu Konfederasyon Grubu olarak yeniden adlandırılmıştır (www.guengl.eu).

"Başka Bir Avrupa Mümkün" sloganı ile alternatif Avrupa modeli sinyali veren GUE/NGL, cinsiyet eşitliği, insan haklarını güçlendirme, anti-faşist ve anti-ırkçı politikaları destekleme gibi hedefleri vardır. Daha fazla vatandaş katılımıyla AB'yi salt elitler projesi olmaktan çıkarıp halkın projesi haline dönüştürmek istemektedir (Demirel, 2014: 144-145).2014 y1linda yapılan Avrupa Parlamentosu seçimlerinde GUE/NGL tarafindan vurgu yapılan konular mevcut Avrupa Mali Altyapısı askıya alınması ve dayanışma ile büyümeyi sağlayacak, sosyal

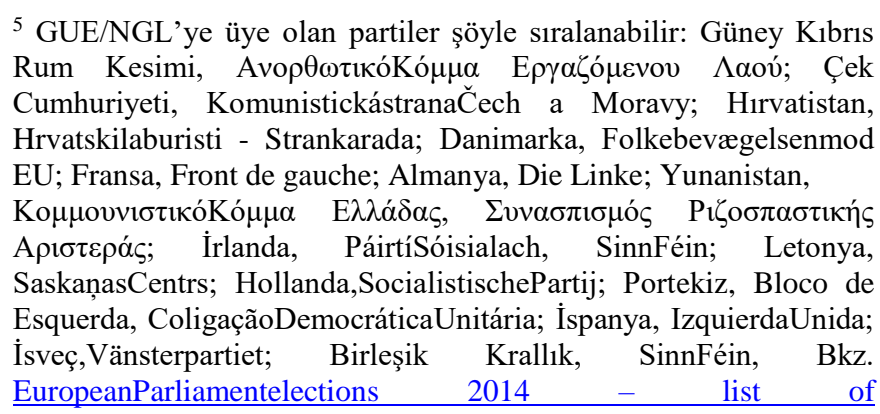
puropeanParliamentelect

http://en.europewewant.eu/files/2014/04/EP-political-groups-andparties.pdf, (Son Erişim Tarihi:13.02.2016). 
ihtiyaçları karşılayacak bir yapının ortaya konması, zenginlerin bütçeye daha çok katkı yapmaları, yoksullardan yapılan kesintilerin durdurulması, göç altyapısında reformlar yapılmas1, demokratik reorganizasyon ve ulusal egemenliğe sayg1, Avrupa ülkelerinin ABD, NATO gibi ülke ve örgütlere karşı bağımsızlığının sağlanması, üretimin ekolojik dönüşümü için harekete geçilmesidir (www.guengl.eu).

\section{f. Avrupa Özgür İttifakı/Yeşiller Grubu (EFA/G)}

Avrupa Özgür İttifakı, 1981 yılında benzer görüşlü siyasi partilerin ittifakı olarak kurulmuştur. EFA üye partileri, 1999 yılında Parlamento'da grup kurmuşlardır. EFA bünyesinde 40 parti bulunmaktadır ve parlamento üyeleri vatansız uluslardan, bölgelerden ve azınlıklardan oluşmaktadır. 20142019 dönemi için parlamento üyeleri; Katalonya, Galiçya, Letonya, İskoçya, Valencia, Galler ve Bask’tan seçilmiştir (http://efa.greens-efa.eu). ${ }^{6}$ Grubun siyasî tutumuna geniş çerçeveden göz atıldığında, temel insan haklarına saygılı bir toplum oluşturmak, iş istihdamını arttırarak AB vatandaşlarına çalışma özgürlüğünü sağlamak, bireylerin karar alma sürecine doğrudan katılımını ve yerinden yönetimi sağlayarak şeffaflığını güçlendirip demokrasiyi derinleştirmek, özgür bireylerin “AB”ni inşa etmek temel hedefler arasındadır (www.siyasaliletisim.org).

Yeşiller ise 1970'li yıllardan sonra ekolojik konuların önem kazanması ile ulusal siyasi arenalarda boy göstermeye başlamışlardır. Bazı noktalarda görüş ayrılıkları bulunan Yeşil partiler, 1984 yılında bir araya gelerek ortak Yeşil bilinci oluşturabilmek maksadıyla Avrupa Yeşil Partiler Koordinasyonunu oluşturmuşlardır. 1993 yılında ise bu koordinasyon, ekolojik, demokratik, sosyal ve barışçıl bir Avrupa hedefi ile Avrupa Yeşil Partiler Federasyonu'na dönüşmüştür. 1999 seçimlerinden beri işbirliği içerisinde olanAvrupa Özgür İttifakı ve Yeşiller, AP'nin altıncı büyük grubunu oluşturmaktadır. Diğer gruplardan farklı olarak grup, eş başkanlık sistemi ile yürütülmekte ve tüm kadrolarda cinsiyet eşitliği garanti altına alınmış durumdadır.

Avrupa Özgür İttifakı ve Yeşiller birleştikten sonra hedeflerini revize ederek şu şekilde açıklamışlardır (Güler, 2011: 121-122); doğaya ve insan haklarına saygilı bir toplum yaratmak, iş hayatında insanların potansiyellerini ortaya koyabileceği bir atmosfer yaratmak ve özgürlükleri genişletmek, AB vatandaşlarının yerel karar mekanizmalarında daha çok söz sahibi olmasını sağlayarak demokrasiyi derinleştirmek. EFA/G, piyasa kurallarının temel sosyal hakları çiğnemesine müsaade edilmemesi gerektiğini düşünmektedir. Özellikle sosyal ve sağllk hizmetlerini $\mathrm{AB}$ düzeyinde serbest piyasa mevzuatından uzaklaştırmak

${ }^{6}$ Avusturya, DieGrünen - DieGrüneAlternative; Belçika,Ecolo, Groen, Nieuw-VlaamseAlliantie; Danimarka, SocialistiskFolkeparti; Finlandiya, Vihreäliitto; Fransa, Europe Écologie - LesVerts, U Partitudi a NazioneCorsa; Almanya, Bündnis 90/DieGrünen;

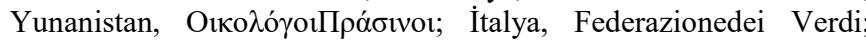
Letonya, Par cilvēkatiesībāmvienotāLatvijā; Lüksemburg, DéiGréng; Hollanda, GroenLinks; İspanya, Equo, EsquerraRepublicana de Catalunya, IniciativaperCatalunyaVerds, EuskoAlkartasuna, BloqueNacionalista, Galego; İsveç, Miljöpartiet de Gröna, Piratpartiet; Birleşik Krallık, PlaidWerddCymru a Lloegr, ScottishNationalParty, PlaidCymru - Party of Wales, Bkz. $\begin{array}{llllll}\text { EuropeanParliamentelections } & 2014 \quad & - & \text { list } & \text { of }\end{array}$ politicalgroupsandparties,

http://en.europewewant.eu/files/2014/04/EP-political-groups-andparties.pdf, (Son Erişim Tarihi:13.02.2016). istemektedir. Ayrıca, küresel mali sektör için daha etkili düzenlemeler ve daha şeffaf bir piyasa istemektedir. EFA/G; iklim ve çevrenin korunması için yasal zeminde adımlar atılması gerektiğini ifade etmektedir. Grup; kalıcı sosyal ve istihdam yasalar ile birlikte sürdürülebilir, yeșil ekonomiye geçiş için teşvik etmektedir. Grup, enerjinin etkin kullanımının, yenilenebilir enerji kaynaklarına geçişi teşvik etmenin ve nükleer enerjiye müsaade edilmemesinin önemine vurgu yapmaktadır.Grup; AB sınırları içerisinde olduğu gibi, sınırları ötesinde de siyasi ve ticari bağlantıları vasıtasıyla barışı, istikrarı, demokrasiyi ve insan haklarını teşvik etmesinin gerektiğini ifade etmektedir. Grup, AB politikasında gerçek bir insan hakları kültürü inşa etmek istemektedir. EFA/G, ayrımcılık ve tahammülsüzlük ile mücadele etmektedir.Grup, internetin ticari kullanımından vazgeçilerek entelektüel refah maksadıyla kullanılması için görüşlerini açık bir şekilde savunmaktadır. EFA/G'nin gündeminde olan bir diğer konusu ise kültürel değerlerin korunmasidır (www.greens-efa.eu).

\section{g. Avrupa Özgürlük ve Demokrasi Grubu (EFD)}

2009 y1lında kurulan siyasi grup, Parlamento'nun en kozmopolit grubudur. Sağ ve sol partiler bünyesinde yer almaktadır. Parlamento'da AB'ne muhalif sağ kanat arasında yer almaktadır. Grup, Parlamento'da temsil edilen yedinci büyük gruptur.

Avrupa'nın bürokratikleşmesine, merkezi tek $\mathrm{AB}$ modeline ve merkezileştirme yönündeki tüm çabalara karşı çıkmaktadır. Fakat bu karşıtlık, AB'yi mutlak reddediş olarak algılanmamalıdır. EFD, AB yönetişim biçimini eleştirmekte ve gelecek Avrupa'sı için önemli olan demokratik gereklilikleri yerine getirmek için politika üretmenin önemine vurgu yapmaktadır (Akbaba, 2014: 499-500). EFD geleneksel ulusal anlayış dışına taşan tutumları ve bunun sonucunda post-milliyetçi siyasi çekişmenin önemli bir parçası haline gelen ve zaman zaman katı bir muhalefet içinde zaman zaman ise direnç ve baskı gösteren bir hareket içinde ele alınmıştır. Grubun en önemli iki hedefí; saydamlık ve demokrasinin geliştirilmesidir. EFD, egemen devletlerarasında demokrasi ve özgürlük temellerine dayalı işbirliği modelini savunmaktadır. Bunlarla birlikte Avrupa'nın tarihi, gelenekleri ve kültürel değerleri ile ulusal farklılıklar ve çıkarlara saygı duyulması EFD açısından önem taşırken yabancı düşmanlığı, Anti-Semitizm ve her türlü ayrımcılığa karşı çıkmaktadır (Karluk, 2014: 398). Grup ve bünyesindeki ulusal partiler, mali birliğe olduğu gibi Lizbon Antlaşması'na da karşı çıkmaktadır. Demokrasi ve meşruiyet, grup tarafindan en çok vurgu yapılan iki konudur. İç tüzükte, demokrasi ve meşruiyete şu şekilde vurgu yapılmıştır (Akbaba, 2014: 505-511):

Demokrasi, özgürlük ve ulus
devletlerarasındaki işbirliği ilkelerine bağll,
Avrupa devletleri arasında açı, şeffaf,
demokratik ve hesap verebilir işbirliğini
destekleyen ve Avrupa'nın bürokratikleşmesini
ve merkezileşerek tek bir Süper-Avrupa
oluşturulmasını reddeden grup... Mevcut bütün
antlaşmalar ve düzenlemeler özgür ve adil bir
şekilde üye devletlerde oylamaya sunulmalıdır.
Grup, AB vatandaşlarının iradelerinden gelen
güce ve onların özgür ve demokratik
yönetimine inanmaktadır.




\section{h. Uluslar ve Özgürlükler Avrupası (ENF)}

Uluslar ve Özgürlükler Avrupası (ENF), siyasi grupların en yeni üyesidir. Radikal sağ kanatta Uluslar ve Özgürlükler Avrupası'ndan önce en son teşebbüs 2007 y1lında Kimlik, Gelenek ve Egemenlik grubu ile olmuştur. Bir y1l süren bu teşebbüs başarısızlık ile sonuçlanmıştır (http://europedecides.eu). En az yedi ülkeden üye kriterini yerine getiremeyen aşırı sağcılar, 2014 yılında yapılan Avrupa Parlamentosu seçimleri ile bu kriteri yerine getirmeyi başarmış ve Marine Le Pen ile Hollandalı aşırı sağcı Marcel de Graaff eş başkanlığında 16 Haziran 2015 tarihinde Uluslar ve Özgürlükler Avrupası Grubu'nu oluşturmuşlardır. Grupta Fransa'dan Ulusal Cephe, İtalya'dan Kuzey Ligi, Avusturya'dan Avusturya Özgürlük Partisi, Hollanda'dan Özgürlük Partisi, Belçika'dan Flaman Çıkarı gibi siyasi hareketler yer almaktadır. Grubun, Parlamento'da sekiz üye ülkeden 36 temsilcisi bulunmaktadır.

ENF, Avrupa projesine karşıt aşırı sağ ve göçmen karşıtlığı politikaları ile ön plana çıkmaktadır. Seçmenlerden gelen politik gücün resmi $\mathrm{AB}$ kurumlarına devredilmesine karşı çıkmaktadır (www.janiceatkinson.co.uk). Grubun vaatleri arasında egemenlik, toplu göç sorununu bitirmek, demokrasi ve özgürlük bulunmaktadır. Avrupa projesine karşı çıkan ENF aynı zamanda Türkiye'nin AB'ye üyelik sürecine gösterdiği olumsuz tepki ile de ön plana çıkmaktadır.

\section{i. Bağımsızlar}

Avrupa Parlamentosu'nda grupların yanı sıra bağımsız üyeler bulunmaktadır. Müstakil veya zaman zaman beraber hareket eden bu bağımsız üyelerin de bazı hakları bulunmaktadır. Örneğin; 40 bağımsız üye bir araya gelerek Başkan ve Başkan Yardımcılığı seçimleri için aday çıkarabilir. Bağımsız üyelerden biri Başkanlar Konferansı'na davet edilir fakat oy kullanma hakkı yoktur. Bütün üyeler, yasa teklifinde bulunma hakkına sahiptir. Bu yasa teklifleri, komite tarafından onaylanarak işleme sokulur. Bağımsız üyeler de grup üyeleri gibi, diğer $\mathrm{AB}$ kurumlarının gözetiminde rol üstlenmektedirler. 40 ve daha fazla parlamento üyesi bir araya gelerek Konsey veya Komisyon'a sözlü olarak soru önergesi verebilir. Bunların dışında, bütün bağımsız üyeler oylamalarda bir dakika açıklama yapabilirler (Poptcheva, 2015: 3).

\section{Siyasal Grupların Politikalarının Karşılaştırması}

Avrupa Parlamentosu siyasi grupları, yapılarının kozmopolit olmaları ve kurumsallaşmalarının ulusal partilere göre daha yeni olmasından dolayı politika alanlarında daha esnek ve yüzeysel tutum sergiledikleri söylenebilir. Siyasi grupların tutumunu belirleyen faktör ise kendisini oluşturan ulusal partilerin genel yönelimidir. Siyasi grupların politikalarının karşılaştırılmasına yönelik Avrupa Parlamentosu seçimleri için ulusal parlamentolar tarafindan kullanılan bildirgeler (EMP data, MannheimÜniversitesi) ve partilerden ve seçmenlerden edinilen bilgiler 1şı̆̆ında hazırlanan AB Profiler verilere (Avrupa Üniversite Enstitüsü, Florence) dayalı çalışmalar siyasi grupların politika ağırlıklarını göstermektedir.
Tablo 3: Siyasi Grupların Politika Öncelikleri

\begin{tabular}{|c|c|c|c|c|c|c|c|}
\hline & EPP & S\&D & ALDE & EFA/G & GUE/NGL & ECR & EFD \\
\hline Uluslararası İşbirliği & 12,7 & 14,3 & 9,2 & 8,3 & 7,8 & 5,3 & 1,8 \\
\hline Askeri Güç & 3,8 & 1,4 & 1,6 & 0,1 & 0,2 & 1,2 & 0,3 \\
\hline Ulusçuluk & 1,9 & 1,1 & 1,9 & 1,3 & 3,2 & 5,3 & 30,5 \\
\hline Genișlemeler & 3,9 & 1,1 & 2,1 & 0,8 & 0,5 & 0,1 & 2 \\
\hline \multicolumn{8}{|l|}{ Kurumsal Olaylar } \\
\hline AB Pozitif & 10,2 & 8,1 & 5,7 & 8,2 & 5,8 & 6,5 & 2,8 \\
\hline AB Negatif & 3,1 & 1,7 & 3,6 & 2,6 & 5,1 & 20,8 & 12,7 \\
\hline Demokrasi & 2,8 & 4,3 & 4,9 & 5,4 & 5,9 & 3,3 & 7,6 \\
\hline \multicolumn{8}{|c|}{ Sivil Özgürlükler, Adalet ve İç İșleri } \\
\hline Özgürlükler & 2,4 & 2,1 & 3,5 & 5,6 & 4 & 1,5 & 3 \\
\hline $\begin{array}{l}\text { Geleneksel Ahlak, } \\
\text { Düzen }\end{array}$ & 6,6 & 4,3 & 5,4 & 1 & 1,8 & 9,8 & 5,9 \\
\hline \multicolumn{8}{|l|}{ Ekonomi ve Para Birliği } \\
\hline Piyasa Ekonomisi & 6,4 & 5,4 & 11,9 & 2,6 & 3,6 & 7,4 & 4,4 \\
\hline Planli/Karma Ekonomi & 1 & 1,5 & 1 & 1,1 & 7,9 & 1,6 & 1,3 \\
\hline Ekonomik Altyapı & 6 & 5,5 & 5,7 & 1,3 & 2 & 1,1 & 2 \\
\hline \multicolumn{8}{|l|}{ Sosyal İşler } \\
\hline $\begin{array}{l}\text { Refah Devleti } \\
\text { Sinırlandırılmas1 }\end{array}$ & 0,1 & 0 & 0,1 & 0 & 0 & 0,4 & 0,1 \\
\hline $\begin{array}{l}\text { Refah Devleti } \\
\text { Genişlemesi }\end{array}$ & 7 & 13,8 & 7,6 & 10,4 & 14,5 & 1,6 & 1,2 \\
\hline Sosyal Grup Politikas1 & 0,3 & 0,5 & 0,2 & 0,6 & 0,3 & 0 & 0 \\
\hline \multicolumn{8}{|l|}{ Çevre } \\
\hline Doğanın Korunması & 4,1 & 6,6 & 8,2 & 24 & 7,5 & 3,9 & 4,3 \\
\hline \multicolumn{8}{|l|}{ Tarım } \\
\hline Tarım & 3,1 & 2,5 & 3,6 & 3,7 & 2,1 & 5,9 & 0,5 \\
\hline
\end{tabular}

Kaynak:http://www.eui.eu/Projects/EUDO/Documents/EUDOReport2web.p df(Son Erişim Tarihi:22.03.2016)

Tablo mercek altına alındığında (www.dbresearch.com):

a. Parlamento'nun büyük bir çoğunluğunu oluşturan EPP, S\&D, ALDE, EFA/G, GUE/NGL hem AB içerisinde hem de $\mathrm{AB}$ dışındaki ülkeler ile ilişkilerin geliştirilmesine yönelik olumlu yaklaşım sergilemektedir.

b. Özellikle Brexit sürecinden sonra $\mathrm{AB}$ gündeminin en popüler konusu AB'nin geleceği ve genişlemesidir. Avrupa sınırlarının kaldırılması aşırı sağcıların karşı çıktığı ve seçimlerde ön planda tuttuğu konulardan birisidir. EFD, bu grupların çok büyük farkla başında yer almaktadır. Avrupa bütünleşmesi karşıtlığı, 2016 yılında kurulan aşırı sağ Uluslar ve Özgürlükler Avrupası grubunun da en temel argümanıdır. Genişlemeye yönelik politikaların en güçlü savunucusu ise EPP'dir.

c. AB'nin kurumsallaşması, genişlemeye bakış açısına paralel olarak siyasi grupların tutum sergilediği alanlardan birisidir. AB kurumsallaşmasının savunucuları arasında EPP, S\&D ve EFA/G; karşıtları arasında ise ECR ön plana çıkmaktadır. EPP, Konsey'in karar alma mekanizmasındaki tek merkez organ olması gerektiğini ifade etmektedir. S\&D, Parlamento'nun yasama, bütçe ve kontrolü görevlerini aksaksız bir şekilde yerine getirmesinin altını çizmektedir. ALDE, kurumların çalışma yöntemlerinin yeniden düzenlenmesi ve iş yükünün hafifletilmesi gerektiğini, AP'nin yetkilerinin arttırılmasını söylemlerinde ifade etmektedir. EFA/G, ulusal veto haklarının azaltılmasından yanadir.

ç.AB'nin temel değerlerinden birisi olan demokrasi ise siyasi grupların yakın oranlarla öncelik verdiği konulardan birisidir. Özgürlük ise EFA/G'nin diğer gruplara göre ön planda tutulduğu konulardan birisidir. Geleneksel düzenin en şiddetli savunucusu ise AP'nin muhafazakâr partisi ECR'dir.

d. Ekonomide ise piyasa ekonomisi ALDE başta olmak üzere ECR, EPP ve S\&D; planlı ve karma ekonomi GUE/NGL için önem taşımaktadır. EPP'nin AB ve euro bölgesinin nihai olarak birleşmesini, ulusal bütçeler ve 
ekonomik stratejiler arasında daha s1k1 koordinasyonla AB'nin gerçek siyasi birlik haline dönüştürülmesini hedeflediği görülmektedir. S\&D ise ekonomik ve mali politikaların koordinasyona ve bu politikalar üzerinde AP ve ulusal parlamentolar tarafindan demokratik kontrol mekanizmaları oluşturulmasına vurgu yapmaktadır. Euro bölgesinin siyasi olarak birleşmesini savunan ALDE'ye göre AB topraklarının tamamında ekonomik aktivitelerin ahenkli dağılımı teşvik edilmelidir. EFA/G, şeffaflığa ve ekonomik istikrara vurgu yapmaktadır.

e. Sanayi ve rekabet politikalarında, EPP'ye göre $A B$ içerisindeki endüstriyel taban güçlendirilmelidir. Ulusal düzeyde ve $\mathrm{AB}$ düzeyinde başta gençler olmak üzere girişimciler teşvik edilmelidir. S\&D, KOBI'lerin desteklenmesini söylemlerinde kullanmaktadır. ALDE'de büyümeyi sürdürme amacıyla rekabetin teşvik edilmesinden yanadır. EFA/G, sanayinin KOBİ ve kooperatifleri teşvik etmesiyle yenilik odaklı yeşil dönüşümde kilit rol oynamayı sürdürmesini söylemektedir.

f. Parlamento içerisindeki tüm gruplar AB'nin sosyal alandaki kısıtlamalarına şiddetli bir şekilde karşı çıkmakta ve refahın arttırılmasına yönelik uygulamaları teşvik etmektedir. EPP, genç kadınlar ve yaşlı işçilerin işgücüne dâhil edilmemesi, işsiz insanlara firsat tanınması, genç işsizliğine karşı örnek uygulamaların yaygınlaştırılması, emeklilik yaşının yükseltilmesi,ulusal iş yasalarına göre ülkeye özel asgari ücret belirlenmesi gibi konular üzerinde durmaktadır. S\&D için istihdam, eğitim ve sosyal uyum üzerinde bağlayıcı hedeflerin belirlenmesi önemlidir. Cinsiyet eşitliği, asgari ücretin AB'ye uygun standartlarda olması, Gençlik Garantisi için ayrılan bütçenin arttırılması, işçi haklarının koruma altına alınması, ticari birlik haklarının güçlendirilmesi S\&D tarafından vurgulanmaktadır. Etkili bütünleşme ve katılım politikaları uygulamaya konmalıdır. ALDE, Avrupa Sosyal Modeli'ni desteklemektedir. Dezavantajlı bölgelerin gelişimine yönelik kaynakların arttırılmasını ve her türlü ayrımcılık ile mücadele edilmesini savunmaktadır. EFA/G, minimum sosyal standartların belirlenmesi ve uygulanması görüşündedir. İşyerlerinde kadınlar için kontenjan ayrılmalı, bu kontenjan 2020 yılına kadar \%40'a çıkarılmalıdır. Kamu hizmetlerine erişim için yaş sınırı olmamalıdır.

g. Çevrenin korunmasına en önem veren grubun EFA/G olduğu görülmektedir. Tarım politikalarında ise ECR ön plana çıkmaktadır.

Siyasi grup politikalarının karşılaştırması üzerine yapılan bir başka çalışmada, Euro-Manifestolar tarafindan belirlenen siyasi grup öncelikleri tablo halinde aşağıda belirtilmiştir;

Tablo 4: Euro-Manifestolar Tarafindan Belirlenen Siyasi Grup Öncelikleri-2

\begin{tabular}{|c|c|c|c|c|c|c|c|}
\hline & EPP & S\&D & ALDE & EFA/G & GUE/NGL & ECR & EFD \\
\hline Liberal Toplum & 5,4 & 12,8 & 11,5 & 17,7 & 16,3 & 9,7 & 7,7 \\
\hline $\begin{array}{l}\text { Ekonomik } \\
\text { Liberizasyon }\end{array}$ & 10,3 & 4,8 & 10,1 & 3,1 & 4,5 & 10,7 & 13,4 \\
\hline Kısıtlayıcı mali politika & 10 & 4,8 & 10,6 & 3,9 & 5,3 & 10,5 & 13,2 \\
\hline Hukuk ve Düzen & 16 & 8,6 & 9,7 & 2 & 5,3 & 12,3 & 14,8 \\
\hline $\begin{array}{ll}\begin{array}{l}\text { Kısıtlayıcı } \\
\text { Politikası }\end{array} & \text { Göç } \\
\end{array}$ & 12,3 & 7,9 & 9,1 & 5,7 & 6,8 & 7,4 & 16,9 \\
\hline Çevreyi Koruma & 9,1 & 15,2 & 10,7 & 17,4 & 16,2 & 9,6 & 5,3 \\
\hline $\begin{array}{l}\begin{array}{l}\text { Genișletilmiş } \\
\text { Devleti }\end{array} \\
\text { Refah }\end{array}$ & 10 & 16,9 & 10,7 & 17,6 & 19 & 11,3 & 8 \\
\hline
\end{tabular}

Kaynak:http://www.eui.eu/Projects/EUDO/Documents/EUDOReport2web. pdf(Son Erişim Tarihi:26.03.2016)
Yukarıdaki tablo ise şunları ifade etmektedir;

a. Bireysel hak ve özgürlükler genel olarak tüm gruplar için büyük öneme sahiptir. Bununla birlikte liberal toplum politikaları EFA/G ve GUE/NGL'de daha çok ön plana çıkmaktadır. Avrupa Halk Partisi'nin daha az etkin olduğu görülmektedir.

b. EPP, AB içerisindeki sermaye ve para hareketliliğini canlandıracak, kısıtlamaları ortadan kaldıracak böylece AB ekonomisini güçlendirecek ekonomik liberal politikaların ALDE, ECR ve EFD ile birlikte destekçisidir. $\mathrm{AB}$ içerisinde sermaye ve para hareketliliğini sağlayacak en önemli araçlardan birisi tek pazardır. Grupların Tek Pazar politikalarına bakıldığında EPP'nin işgücü hareketi ve esneklik ile Dijital Tek Pazar'ın tamamlanmasına, ALDE'nin ticaret ortaklıklarının geliştirilmesine ve Tek Telekomünikasyon Pazarı oluşturulması ile bilginin serbest dolaşımına, EFA/G'nin Tek Pazar'ın daha az gelişmiş ülkelere doğru açılmasına önem verdiği görülmektedir (www.dbresearch.com).

c. Kısıtlayıcı mali politikaların uygulanmasını EPP, ALDE, ECR ve EFD benimserken; S\&D, EFA/G ve GUE/NGL bu uygulamalara daha negatif yaklaşım sergilemektedir.

d. Hukuk ve düzen konusuna özellikle EPP, ECR ve EFD vurgu yapmaktadır. S\&D ve ALDE ortalarda yer almakla birlikte onları EFA/G veGUE/NGL takip etmektedir.

e. Kısıtlayıcı göç politikalarının uygulanmasını en çok EPP ve EFD savunurken S\&D, ALDE, EFA/G, GUE/NGL ve ECR onların arkasından gelmektedir (http:/beucitizen.eu).

f. Ortak çevre politikalarında AP içerisinde en duyarlı grupların GUE/NGL ve EFA/G olduğu görülmektedir (Duru, 2002: 7-25).

g. AB'de refah devleti (Şenkal ve Sariipek, 2007: 146-175) uygulamalarını özellikle S\&D, EFA/G veGUE/NGL savunmaktadir.

Sosyalist ve demokratlar ise çevrenin korunması ve refah politikalarında ön planda olduğu dikkat çekmektedir. ALDE ise tüm göstergelerin ortasında yer alarak sağ ve solu ikiye bölmektedir. Ekonomi politikalarında ise ALDE'yi EPP ve ECR'den ayırmak zordur. Bu gruplar, daha çok hukuk ve düzen boyutunda farklılık göstermektedir. EFD, EPP ile hukuk ve düzen politikasında benzer olmakla birlikte EFD daha kısıtlayıcı göç politikalarını ve neo-liberal ekonomik politikaları desteklemektedir.

Avrupa'nın çok genç bir nüfusa sahip olmamasından dolayı gençlik potansiyelini doğru politikalarla değerlendirmek önem taşımaktadır. Daha çok üye devletlerin söz sahibi olduğu bu politikalarda üye devletlerarasındaki işbirliğgi $A B$ tarafından teşvik edilmektedir ( $A B$ Bakanlığ Sosyal, Bölgesel ve Yenilikçi Politikalar Başkanlığı, AB'nin Gençlik Politikaları Bilgi Notu, www.ab.gov.tr).Avrupa Parlamentosu'nun büyük çoğunluğunu oluşturan EPP, S\&D, ALDE, EFA/G, GUE/NGL'nin gençlik politikaları kıyaslandığında; EPP'nin işgücü hareketliliği ile ilgili eğitim ve uygulamalara, S\&D'nin çalışma ortamında yüksek standartların olușturulmasına, GUE/NGL'nın mobil işçilere yapılan ayrımcılık ile mücadele edilmesine, EFA/G'nin firsat eşitliğine ve beyin göçüne yönelik tedbir alınmasına, ALDE'nin üye devletlerarasında genç nüfusun hareketliliğine ve Avrupa vatandaşı olarak sahip olduğu medeni haklara vurgu yaptığı görülmektedir. 
Enerji politikasında EPP, istikrarlı ve sürdürülebilir enerji kaynaklarının sağlanmasını hedeflemekte (http://www.eppgroup.eu) ve ortak enerji politikasının yürütülmesine işaret etmektedir. S\&D ise sektörel kurallar, sektöre yatırım ve enerjiye erişime işaret etmektedir. ALDE içinse öncelik etkili yenilenebilir enerji üretimi için ar-ge çalışmalarının arttırılmasıdır. EFA/G'ye göre kapsamlı bir iklim ve enerji politikası geliştirilmelidir. Nükleer enerji kademe kademe bitirilmelidir (www.dbresearch.com).

Avrupa Parlamentosu'nun en büyük iki grubu olan EPP ve S\&D'nin politikalarının karşılaştırmasının ve ortak kesişim alanlarının bilinmesinin yakın geleceği okumak açısından fayda sağlayacağı değerlendirilmektedir. Ekonomik büyüme her iki grup için de önemli olmakla birlikte ekonomik politikalarda EPP, AB'yi daha fonksiyonel ve k1sitlı bir rolde konumlandırırken S\&D daha aktif bir rol vermektedir. Temel hak ve özgürlükler her iki grubun temel değerleri arasında yer almakla birlikte EPP'nin özgürlüklere, S\&D'nin eşitliğe ağır basan bir yönü olduğu söylenebilir. Çevre konusunda her iki grup da benzer politikalar sergilemekte ve Avrupa'nın geleceği için yeşilci çözüm ve uygulamalara gidilmesinin, bu konuda ar-ge alanında yatırımlar yapılmasının önemine işaret etmektedir. Sosyal politikalarında her iki grup da kadınların sosyal haklarına önem vermekte ve cinsiyet ayrımcılı̆g ile mücadeleye vurgu yapmaktadır. İş gücü pazarının entegrasyonu ve politikalarda uzlaşma her iki grup açısından da önem taşımaktadır. İki grup da iç pazara ve ekonomik büyümeye işaret etmektedir (http://beucitizen.eu).

Genel olarak tablolar, siyasi grupların bir konu üzerinde ağırlık merkezi oluşturduğunu göstermektedir. Merkezde yer alan liberal ALDE için piyasa ekonomisi, Yeşiller için çevre, Komünist GUE-NGL için refah devleti, muhafazakâr ECR için hukuk ve düzen, EFD için Avrupa şüpheciliği ve kısıtlayıcı göç politikaları, S\&D için liberal toplum ve refah devleti, merkez-sağ boşluğu dolduran EPP için piyasa odaklı ekonomi politikası önem arz etmektedir.

Dikkat çeken bir diğer nokta ise siyasi gruplarda klasik sağ/sol ideoloji çizgisinin belirginsizleşmesidir. Siyasi grupların politikaları, seçim manifestoları incelendiğinde sağ grupların popülist hedefler için zaman zaman sol kanat argümanları kullandığı, sol partilerin de aynı şekilde sağ kanat argümanları kullandığı görülmektedir (https://www.sh.se). Bu durumun temelinde grupların siyasi yarışta pragmatizm esaslı hareket etmesi, kozmopolit bir yapıya sahip olmaları ve geniş seçmen kitlesi içerisinden mümkün olduğunca çok seçmene hitap etme arzusu yatmaktadır.

\section{Kaynaklar}

Akbaba S. (2014), "Post-Milliyetçi Avrupa Bütünleşmesi İçinde Avro-Kuşkuculuğun Rolü: Avrupa Özgürlük Ve Demokrasi Grubu Vaka Analizi”, International Journal of SocialScience, Say1:24, 499-515.

\section{Siyasi}

Akçadağ, E., "Avrupa Parlamentosu ve Parlamentodaki http//www siyasaliletisim. Gruplar", salgruplar.pdf

BressanelliE. (2010),TheEuropeanParliamentafterLisbon: PolicyPositionandIdeologicalCoherence thePoliticalGroups, Venice, 16-18 SISP Congress,

\section{Sonuc}

$\mathrm{AB}$, geleceği oldukça tartışmalı bir organizasyon olsa da Avrupa toplum modelinin geldiği noktayı göstermesi bakımından önemini korumaktadır. Avrupa tarihinden ve başlıca Avrupa ülkelerinin siyasal sistemlerinin gelişiminden yola çıkılarak AB kurumları içinde Avrupa Parlamentosu ayrı bir yere konabilir. Bu konuda iyimser bir bakıș açısıyla Avrupa Parlamentosu, konumu ve yetkileri gereği, Avrupa Birleşik Devleri gibi bir isimle anılabilecek bir devasa devletin yasama organı olma özelliğini taşımaktadır. Parlamentodaki siyasi gruplar da gerek $\mathrm{AB}$ gerekse de siyasi partiler tartışmaları bakımından özgün bir yere sahiptir.

AP Siyasi Grupları, ulusal düzeydeki siyasi partilerle hem benzeşen hem de farklı yönlere sahiplerdir. Siyasi grupların, klasik siyasi partilerle benzeşen yönlerine örnek olarak, sağ ve sol yelpazesinde belli bir ideolojik dağılıma sahip olmaları, seçmen desteğine ihtiyaç duymaları, bir organizasyon yapilarının ve idari ofislerinin bulunması, tarihsel kökenlere sahip olmaları gibi özellikler verilebilir. Farklılaşan yönlerine örnek olarak ise; siyasi grupların ulusal siyasi partilere göre, özellikle de seçmen nezdinde daha soyut ve karmaşık organizasyonlar olmaları, ulusal partileri üye yöntemi ile çatıları altında bulundurmaları, seçim dönemleri ve sonrasında üye partilerin değişebilmesi dolayısıyla sürekli değişebilir hatta kendi içinde çelişebilir yapılar olmaları gibi özellikleri sunulabilir. Siyasi grupların, siyasi partilerin değişimi ve geleceği tartışmaları başlığında da önemli bir yerleri olduğu iddia edilebilir.

AP'nda 1979'da yapılan doğrudan seçimlerle birlikte merkezin sağında ve solunda yer alan iki siyasi grubun baskın bir parlamento çoğunluğu oluşturdukları görülmektedir. 2014 seçimleri sonrasında Avrupa Halk Partisi (EPP) ile Sosyalist ve Demokratların İlerici İttifakı (S\&D) olarak temsil edilmektedirler. Söz konusu iki grup genellikle AP'nda ağırlık sahibidirler. Bununla birlikte $A B$ 'ne farklı tutum ve yaklaşımlara sahip olan gruplar da parlamento içinde yer almaktadırlar. Bunlar içinde liberaller, muhafazakârlar, yeşiller, birleşik sol gibi gruplar da bulunmaktadır. Bu gruplar, birbirlerinden bir yandan ideolojik farklılıklarla diğer yandan da AB'ye bakış açılarıyla farklılaşmaktadırlar. AP da, Avrupa'nın güncel konuları çerçevesinde söylem ve politika geliştirmektedirler. $\mathrm{Bu}$ konular başta $\mathrm{AB}$ entegrasyonu olmak üzere, ekonomi, enerji, gençlik, sosyal hizmetler, çevre, tarım, göç, sanayi ve rekabet ile güvenlik üzerine odaklanmaktadır. Siyasi gruplar özellikle bu konu başlıkları etrafında farklılaşmaktadırlar.

http://www.sisp.it/files/papers/2010/edoardo-bressanelli747.pdf, 1-36.

BressanelliE.

(2012), "NationalPartiesandGroupMembership in theEuropeanParliament: IdeologyorPragmatism?", Journal of EuropeanPublicPolicy, Vol. 19, Issue. 5, 737-754.

BuildingParliament: $\quad 50 \quad$ Years EuropeanParliamentHistory

EuropeanCommunities, Luxembourg, 2009.

Costello

R.,ThomassenJ.VeRosemaM. (2012), "EuropeanParliamentElectionsandPoliticalRepresentat ion: PolicyCongruencebetweenVotersandParties", West EuropeanPolitics, Vol. 35, No. 6, , November, 1226-1248. 
Demirel D. (2014), “Avrupa Parlamentosu: Yapısal Bir Analiz”, KMÜ Sosyal ve EkonomikArastırmalarDergisi,Sayı 26,143-148.

FrantescuD. P. (2015),"ValuesToppleNationality in theEuropeanParliament”, EuropeanView, No: 14, 101-110.

Güler M. (2011), AB Parlamentosu ve Parlamento'nun Temsil Yeteneği, Adalet Yayınevi, Ankara.

Hix S.,NouryA.veRolandG. (2006), “Dimensions of Politics in theEuropeanParliament", AmericanJournal of PoliticalScience, Vol. 50, 494-511.

JacobsF.veBest E. 2004,"TheEuropeanParliament Ready fortheFuture? TheImpact of Enlargement on theEuropeanParliament", EİPAScope, Vol. 3, 14-19.

Karluk S. R. (2014), AB, Beta Yayınları, İstanbul.

Kiriş H. M. (2013), “Avrupa Parlamentosu'nda Siyasal Gruplar ve Parlamento Seçimleri”, Selçuk Üniversitesi Sosyal Bilimler Enstitüsü Dergisi, Sayı 29, 123-135.

Köktaş M. E. (2002), “Avrupa Parlamentosu ve Avrupa Partileri”, Liberal Düşünce, Sayı: 25-26, ss. 89-108.

MarshM. ve NorrisP. (1997),"Politicalrepresentation in theEuropeanParliament", EuropeanJournal of PoliticalResearch, KluwerAcademicPublishers, Vol.32, Issue 2,153-164.

McelroyG.veBenoit K. (2007), "PartyGroupsandPolicyPositionsInTheEuropeanParliament", PartyPolitics, Vol. 13. No.1, 5-28.

Mcelroy G. ve Benoit K.(2015),"PartyPolicyandGroupAffliation in theEuropeanParliament", British Journal of PoliticalScience, Vol. 40, Issue 2, 377-398.

Miller V. (2014), "EuropeanParliamentPoliticalGroups", House Of Commons Library, SN/IA/5031, 1-10.

PoptchevaE.M. (2015), "Rules on PoliticalGroups in the EP”, EurupeanParliament Brifing, June 2015, 1-6.

Roberts J.M. (2010), (Çevirmen:Fethi Aytuna), Avrupa Tarihi, İnkılap Yayınevi, Ankara.

SabbatiG. (2014), EuropeanParliament:FactsandFigures, EuropeanParliamenteryResearch Servise, Brifing November, $1-12$.

Şenkal A.veSaripekD. B. (2007), “AB'nin Karşılaştırmalı Refah Modelleri ve Sosyal Politikada Devletin Değişen Rolü’, Kocaeli Üniversitesi Sosyal Bilimler Enstitüsü Dergisi, Sayı 14, 146-175.

TheEuropeanParliament: Historical Background, FactSheets on theEuropeanUnion - 2015; TheEuropeanParliament: TheCitizen's Voice InThe EU (2014), Luxembourg: Publications Office of theEuropeanUnion.

http://www.EPPgroup.eu

www.ab.gov.tr

www.alde.eu

https://www.aldeparty.eu/en/events/european-elections-

2014 (Son Erişim Tarihi:20.03.2016)

http://www.bbc.co.uk/turkish/specials/1411_eu_parliame nt/page4.shtml, (Son Erişim Tarihi:11.02.2016)

http://beucitizen.eu/wp-content/uploads/Deliverable 9.5_final1.pdf http://www.cvce.eu/obj/the_development_of_political_gr oups_of_the_european_parliament-en-35c2d1b5-1661-4c33a65a-db49ade0c5ac.html, (Son Erişim Tarihi:10.04.2016)

https://www.dbresearch.com/PROD/DBR_INTERNET_E NPROD/PROD0000000000333785.pdf

http://www.dw.com/tr/avrupa-sa\%C4\%9F\%C4\%B1ndant\%C3\%BCrkiye-kar\%C5\%9F\%C4\%B1t\%C4\%B1-

kampanya/a-3995481 (Son Erişim Tarihi:06.03.2016)

http://www.dw.com/en/overview-political-groups-in-theeuropean-parliament/a-4296448 (Son Erişim Tarihi:13.02.2016)

www.ecrgroup.eu

http://efa.greens-efa.eu/267-presentation.html(Son Erişim Tarihi:27.02.2016)

www.en.europewewant.eu

http://www.epp.eu/files/uploads/2015/09/Manifesto2012_

EN.pdf, (Son Erişim Tarihi:11.02.2016)

http://www.EPPgroup.eu/history, (Son Erişim Tarihi:11.02.2016)

http://www.EPPgroup.eu/our-priorities/Economic-

Recovery-and-Jobs, (Son Erişim Tarihi:11.02.2016)

http://www.eppgroup.eu/our-priority/The-EPP-Group'sclimate-and-energy-policy(Son Erişim Tarihi:28.03.2016)

www.eui.eu

https://www.euractiv.com/section/europe-s-

east/news/epp-and-pes-diverge-on-ukraine/ (Son Erişim Tarihi:06.03.2016)

www.europarl.europa.eu

http://europarlamentti.info/en/elections/political-

parties/ideologues-of-the-political-groups/ (Son Erişim Tarihi:13.02.2016)

http://europedecides.eu/wp-

content/uploads/2015/06/EFN-analysis.pdf(Son Erişim

Tarihi:21.03.2016)

http://www.greens-efa.eu/european-union-10.html(Son

Erişim Tarihi:12.03.2016)

http://www.guengl.eu/group/history(Son Erişim

Tarihi:20.03.2016)

http://www.guengl.eu/policy (Son Erişim

Tarihi:24.02.2016)

http://www.janiceatkinson.co.uk/enf/(Son Erişim Tarihi:22.03.2016)

http://www.politico.eu/article/political-groups-selectcommittee-co-ordinators/, (Son Erişim Tarihi:14.12.2015)

https://www.sh.se/p3/ext/res.nsf/vRes/cbees_engelsk_141 2582982411_jaanika_erne_pdf/\$File/jaanika_erne.pdf

http://www.siyasaliletisim.org/pdf/avrupaparlamentosuve siyasalgruplar.pdf (Son Erişim Tarihi:06.05.2016)

http://www.socialistsanddemocrats.eu/policies, (Son 